\title{
Numinose of Play and Its Healing Teleology
}

\author{
Jang, Mikyung* Lee, Yeo Reum**
}

\begin{abstract}
$<$ Abstract $>$
In this article, the numinosity of play in terms of the origin or unique essentiality of play was discussed based on analytical psychology, rather than the evolutionary necessity of it in terms of only biological instinct or innate nature or furthermore, something educated after birth. Attempts to explain play in this aspect lead to the reason why play is healing and play has a powerful relationship with healing in psychotherapy to achieve treatment through play. The still point experience and transference-countertransference and the relationship between the therapist and client which occurs in common, was also discussed with intersubjectivity, that are concepts related the numinosity of play. In conclusion, The essentiality of play which has an archetypal origin, is numinous and divine and has the ultimate teleology of integration and healing of personality, that is individuation. The constellation of archetypal energies by an individual is perceived by other people in close relationships due to the working principle of archetype and all mankind universally shares it and it, in turn, constellate archetypal energy to the other. This, of course, happens in therapeutic relationships, and finally it brings healing to both of the client and therapist who are being involved in archetypal play.
\end{abstract}

Keywords : numinosity, play, psychotherapy, still point, archetype, transference-countertransference

\footnotetext{
* Corresponding author, Main author, Professor, Department of Child Welfare at Namseoul University (Child Counseling \& Psychotherapy) at Graduate School of Namseoul University (jangmiky45@gmail.com)

** Co-author, Doctorate candidate of child counseling and psychotherapy, Department of Child Welfare Studies, Namseoul University
} 
Journal of Symbols \& Sandplay Therapy, Vol.11 No.2.

\section{INTRODUCTION}

Often, play is regarded as an activity for young children. The universal belief is that play is merely an insignificant fantasy or imagination of a child, or a simple repetition or imitation of everyday experiences. Even some play therapists agree to this belief. Many literatures, however, explain that play is an instinct and an innate act of children (Hong \& Lee, 1998; Panksepp, 2007; Garvey, 1977). However, these literatures neither explain nor provide sufficient grounds as to what attributes of play lead to the conclusion that play is instinctive. Instinct is

a biological tendency innate to all organisms; it refers to innate actions and movements or feelings and drives that operate without the intervention of thoughts or emotions (National Institute of the Korean Language, 2019). However, some aspects of play cannot be explained by the instinctive definition - that play occurs without emotional interventions - alone. Researches and literatures on play do not explain how play is similar to or different from biological instinct. Most of them also describe play's effect by focusing only on the outcome (Brown \& Vaughan, 2009). In other words, they do not fully address the origin or essentiality of play, which are important in psychotherapy as they help explain the phenomenon of healing through play that occur between client and therapist.

One of the reasons why the concept or definition of play is so unclear and unorganized is because the attributes of play are difficult to define. Folklore scholar and play theorist Sutton-Smith (2001) mentioned that the word "play" is vague and inaccurate to explain the phenomenon of play. Nevertheless, the explanations of play theorists-although even they find it difficult to define play-hint us that play is not simple and provide some clues about the origin or essentiality of play. Play theorists also define play as being transcendent. Spariosu (1989) says that play belongs to not just one or two domains but to all domains of man. Moreover, Eberle (2014) viewed play as resembling an autonomously organized growth, journey, acceleration, processes that unfold and movement. It is as if architects, molecular physicists, meteorologists, animal behaviorists, political philosophers, economists and urban historians encounter processes that out of their own resources and over time gather shape and structure spontaneously. They observe and study phenomena grouped under the term "emergence," which is "the arising of 
novel and coherent structures, patterns, and properties, during the process of self-organization in complex systems." This voluntary structure is our imagination. It is in sync with the expression that the beginning of science is imagination. Dutch play theorist Johan Huizinga (1980) also says play does not take place based on our intentions.

Stephen Nachmanovitch (1990), who sees art as play based on creative imagination, describes play as being transcendent and divine using the metaphor of a violinist. Nachmanovitch explains that the way a violinist stands firmly on the ground and lifts up one arm up to draw the bow symbolizes the spiritual divinity's descendance to the earth, and the union between the two would create a "paradise" on earth. The violinist and the audience would be deeply moved and experience both psychological and spiritual resonances as an outcome of the paradise. It is not just about playing music through the cerebrum activity; it is a bodily response as well as the experience of the body and the brain becoming one. In that sense, play connects divinity and humanity, brain and body, and reason and emotion. Not only children but also adults pursue sensory play. They run and roll and try to test the limits of their physical body, which is perhaps a task to confirm or manifest the divinity hidden in their body. Seamus Heaney created a poem that provides insights into the invisible divine reality and inspirations from the deep unconscious. He intuited the creative divinity of play that is present in humans.

When I was a child, adults couldn't stop me from going to the water wells and old water pumps in the countryside, with their buckets used to draw out water, and the crank and rope used to lower and lift the bucket out of the well. I loved the depth of the wells, which were dark inside, and how at the bottom, the water reflected the sky, so the sky appeared to be trapped or held within it. I loved also the scents of the wells, with their aquatic plants, mold and mushrooms, and humid moss.

There was one well, in a yard where bricks are made, covered by a wooden top that had started to rot. At this well, I relished the full, crashing sound that the bucket made when it dropped to the end of the rope and hit the water. This well went so far down that you couldn't even see a reflection in the water at the bottom.

There was also a less deep well that had been dug beneath a kind of dry gravel trench. 
Journal of Symbols \& Sandplay Therapy, Vol.11 No.2.

This well was growing plants within it, much in the way that plants would grow within an aquarium. Here, you could pull roots out of the soft soil and broken-down leaves at the bottom of the well; when you did this, you could see your own reflection, looking like a white face suspended in the water.

- Rest is omitted -

(Seamus Heaney, Personal Helicon, Source: http://egloos.zum.com/kangsiin/v/717972)

Given its transcendental aspect, play is also associated with the primal silence. According to the Bible, God's silence preceded his act of creation amid darkness. Therefore, the creative process of imagination that restores human divinity requires silence. We all have the experience of being immersed in play as a child, unaware of what was going on around us or feeling as if we had been to some other world. Such an experience gives us an unidentifiable sense of fullness. Weber-Fechner law states that sensation falls in proportion to stimulus intensity. In other words, turning on a single lamp in a dark room and turning on one more lamp when there already are ten bright lamps in the room feel different in terms of sensation. Compared to the single light that illuminates the dark room, the eleventh lamp does not make a significant difference. This implies that children who are exposed to too many stimuli, such as learning pressure or cell phones, have difficulty experiencing the divinity and healing power of play through immersion. It is common for us to experience divinity in the tranquility of dawn. This is precisely the reason why silence is sometimes necessary for play in psychotherapy (Jang, 2017; Jasinski, 2014). It is not the adults in the outer world who teach children something through play therapy. Rather, it is the play itself that teaches children through the divinity of images of the imaginations. It is difficult to free the ego from the obsession it has developed due to social stereotypes, practices and pressures as well as parenting methods. But the divine nature that creates imagination and manifests it in outer life ultimately brings healing and enables the distorted ego to grow again or become restored. In other words, play imagination has a purposeful function of healing the ego trauma. This is why play has both transcendent and divine qualities.

As grounds for explaining that play is instinctive, Brown and Vaughan (2009) argued that humans and other mammals have instinctive and internalized signals to initiate play. For 
example, a child's gazing at others with a smile or an animal moving in a circular movement or in zigzag instead of a straight line with its eyes wide open are signals of a willingness to play. Even animals engage in play, which seems inefficient and unproductive compared to hunting and breeding. Brown and Vaughan explained that they practice signals and movements not to hunt or fight but to build relationships within a group or a herd. At first glance, it is easy to say that these movements are simply imitative learning. But from the viewpoint of analytical psychology and the theory of archetypes, these movements are a good example of the teleological function, or the energy that guides us to live a life of realizing our whole personality. Rather than specific play behavior, there is an archetypal impulse which is the energy or the essentiality that allows play.

Among scholars who explained and used play in psychotherapy is Donald Winnicott. Winnicott (1971) described play as a transitional phenomenon or a transitional concept for the child's psychological separation and independence. In other words, play serves as a transitional phase, in which there is a differentiation between reality and psychology, others and myself and reality and imagination, prior to becoming psychologically differentiated and independent. This concept implies that play is both instinctive and spiritual, which is very similar to Carl Jung's concept of archetypes (1960/1981). This is because there is a premise that play is not just a biological instinct and that there are some mechanisms or principles behind it. According to Winnicott's concept of play, the transitional phenomenon is not just a temporary phenomenon that is in the "middle" but lasts until the day we die. We know this from experience. This transitional phase that locates between imagination and reality, psyche and reality, and myself and others still exists in adults' realm of imagination and reality and serves as an element that forms arts and culture. This is similar to how Huizinga (1980) viewed play: a cultural phenomenon. If so, we cannot avoid the conclusion that even adults need play, and that play is an archetypal and instinctive impulse of human civilization.

The explanations of these scholars naturally remind us of Jung's concept of archetypes. Although Winnicott neither mentions archetypes nor explained their innate manifestation, he seemed to have known through experience that they are a universal attribute of man. Having existed innately in us since the birth of man, archetypes are a psychic structure that is inherited 
Journal of Symbols \& Sandplay Therapy, Vol.11 No.2.

genetically. Archetypes are preparations for defining and directing human life and behavior and the essentiality to realize them. In particular, the Self archetype is the center of the whole psyche, including the ego, and a central archetype that creates basic ideas that leads the direction of human life. Moreover, the Self archetype is the center of regulation of the psyche. Archetypes are poetic imaginations and fantasies; they emerge in consciousness in the form of basic behavioral drive through imaginations and fantasy images (von Franz, 1996). The constellation of archetypal images is accompanied by strong emotions, and the constellation of the Self archetypal energy, in particular, is a transcendent, divine and elevated experience (Stein, 1998). These strong emotions bring healing and liberate the ego from old traumas and complexes.

But just as it is not the specific play behavior but the instinct to play that is inherited, it is not the archetypal concepts but the potential to form those concepts that is inherited (Jung, 1970). The potential develops in the psyche but at the same time is rooted in instinct; it is the opposite of the same thing. That is why Jung says "the creative activity (play) of the imagination frees man from his bondage to the 'nothing but' and liberates in him the spirit of play" (1954/1993, p. 46). Through play, not only children but also adults can become creative. Man is completely human only when he is playing. Jung did not define human instinct as simply being biological. Jung identified five prominent groups of instinctive factors: hunger, thirst, sexuality, activity and creativity (1960/1981b). Play is not just entirely instinctive but archetypal, which is associated with psychological development. The constellation of archetypal energies is experienced at an emotional level and bring about healing and transformation. Naturally, images of the imaginations can take the form of a play. This is precisely why man has the drive to play regardless of its type and form. The constellation of archetypal images, which are coupled with emotions, functions as the regulating center of the consciousness that is only partially developed or in conflict. By doing so, it bring integration and healing, which is the ultimate teleology of archetypes (Jung, 1960/1981a).

The healing energy, which is constellated together with archetypal images, can affect people around the individual given the universality of the human psyche. This energy field impacts not only the individual but also others, and heals both parties. Children do not heal through play 
therapy simply because they play and laugh. Both children and therapists are affected by the constellation of archetypal energies, thereby experience conflicting emotions, changes in attitudes and perceptions, and healing. This is the moment of transformation. This is the reason why in sandplay, many parents report changes observed in the children even before the parents change in a positive way.

Therefore, there is the need to attempt to explain (1) what and when is the essential moment of transformation within a therapeutic process and (2) how the client-therapist relationship might look like and what their experiences are at that moment of transformation, which were not dealt with in play therapy researches. Naturally, explanations on the origin of play would affect and define the relationship through which play occurs. But to say that therapy is successful simply because the therapist empathized with or understood the client or because the parenting attitude or style changed due to the therapist's intervention-which is the case in existing studies - represents ignorance of the nature of play on the part of the therapist or of the healing function or teleology of play. Such an attitude overlooks the essentiality of the client-therapist relationship or the essential meaning of healing in play for both client and therapist. In such a case, the play therapist would not be able to explain the divine healing power of play. If play is used only as a means or medium, then it does not necessarily have to be play that is used in therapy.

Against such backdrop, this paper aims to, although rudimentarily, review literatures on analytical psychology and play and also discuss the healing teleology of play with regards to the divine aspect of the archetype.

\section{П. EXPERIENCES OF NUMINOSE AND STILLPOINT}

\section{A. Experience of Numinose}

As mentioned above, Jung used the word "archetype" to refer to the principles or mechanisms of play that Winnicott only made implications to. Jung says because archetypes evoke emotions, they are experienced and not understood logically or intellectually. Marie Louise 
Journal of Symbols \& Sandplay Therapy, Vol.11 No.2.

von Franz (1996) says only when an archetypal image has emotional value to man can that image become vivid and have deep meaning. Just as Jung says, we may be able to collect knowledge about all the Great Mothers, sages and other godly men-symbols of divinity and creation-in the world, but not including the related emotional experiences would make the collection meaningless (von Franz, 1996). Emotional experiences that accompany archetypal images enable conflicts to be resolved, integration and healing to take place, and personality to undergo a transition. This is because the archetype has a tendency or teleology to realize the whole of the personality, not just a part of it. And without the accompanying emotional experiences, it cannot have the energy to realize the whole of the personality. This is precisely the reason why the experience of play in play therapy should not be understood as a simple imitation or action; play entails emotions. Healing brought about by psychotherapy methods that use symbols, like sandplay therapy or play therapy, is attributable to the emotional experiences that accompany archetypal images. These emotional experiences have numinous qualities. The word "numinous" is a term derived from the Latin numen, meaning something spiritual, mysterious, divine or supernatural (Otto, 1959). It can be used to refer to the emotional experiences within the client-therapist relationship that give special, mysterious and even divine feelings. Numinosity has been experienced and described in various areas of human culture and experience; it has been called by many different names in a range of genres like religions (Buddhism, Christian mysticism, etc.), literature (poetry, prose, literary criticism), art, music, dance, physics, as well as physical therapeutic methods like yoga, acupuncture, orthodontic bone therapy, parasympathetic therapy, and analytical psychology (Weinberg, 2015).

\section{B. Experience of Stillpoint}

Sometimes, the archetypal or numinous experiences in play are described as the stillpoint. Just as the word itself suggests, stillpoint is a point of stillness, silence and nonverbal. According to Boo and Kang (2016), the stillpoint experience is one in which the past, present and future are not separated and yet intersect and unite; in which both the Chronos time, or the sequential time, and the Kairos time, or the time of significance, exits; and in which the agent and other are not divided but coexist (even life and death are not divided). At the 
moment of stillpoint, one would experience divineness, silence, tranquility, enchantment, and other emotions. When such experience occurs between client and therapist, it warms and thaws frozen emotions like hate, resentment, anger and sadness and allows energy of forgiveness, reconciliation and love to flow. As a result, clients obtain the courage to face things that they have avoided, and the two worlds (the outer world and the inner world, mind and reality, or conflict of the opposites) that were divided or undifferentiated become connected again through the transcendent function. Such an experience completely changes clients' lives (Boo \& Kang, 2016, pp. 2-3).

As emphasized by the word still, the stillpoint experience implies that play is not just a simple activity but is associated with healing silence. Stillpoint is the constellation of a field of energy, and it can take place in both therapist and client. But the stillpoint experience is not necessarily something very grandiose. At times, therapist and client in the therapy room-even without verbal communication-feel solemn, get goosebumps or are deeply moved. The therapist would also feel that something has connected them; that he or she has gained a deeper understanding of the child; or become deeply moved through the sense that the child is feeling something. Sometimes the play therapist is not conscious of that special experience, but only later would come to understand the meaning of that experience or recognize that was a stillpoint moment for the child. An eight-year-old boy client had been suffering from a long-standing conflict between his parents and their lawsuit for divorce. He expressed the psychological instability of his parents as well as the anxiety he felt over the breakup of his family through the play of stacking up toys as high as he could. For a very long time, the child concentrated on the activity without a word. Even when the toys fell down when they went out of balance, the child repeated the activity. The child did not provide an explanation of his behavior, but the therapist could feel what he was trying to do. Amid the long quietness in the room, which was filled with the child's silent energy, the therapist felt the child's deep sadness as well as his healing ability. When the therapist says, "I know it's rather precarious right now but I hope it won't fall and find balance so that you'll fee easy," the child stared at the therapist in the eye without saying a word. Consciously or unconsciously, they both knew that the client was struggling to maintain his inner balance despite anxiety and conflict within 
Journal of Symbols \& Sandplay Therapy, Vol.11 No.2.

home and between his parents. He knew that in order to stack up items that are of different size, shape and weight, he ought to stack them up according to the center of gravity. The play of stacking up figures is not the archetypal experience but the energy that allows the play, which is geared towards overcoming inner conflicts and trauma, is archetypal. And the experience of archetypal energy brings transformation).

This particular feature of play is clearly mentioned in Mary Jane Markell's book Sand, Water, Silence: The Embodiment of Spirit. In this book, Markell (2003, p. 250) mentions the word "mystic center" together with a sandpicture forming the shape of a mandala. It is like the center of energy, and everything around that energy also focuses on that center. At the moment when healing occurs, the archetypal energy of the psyche comes towards the center and comes to face each other, just like the water droplet that is focusing towards the center in the picture below. This explanation is consistent with the experience of when the archetypal image of the Self is constellated.

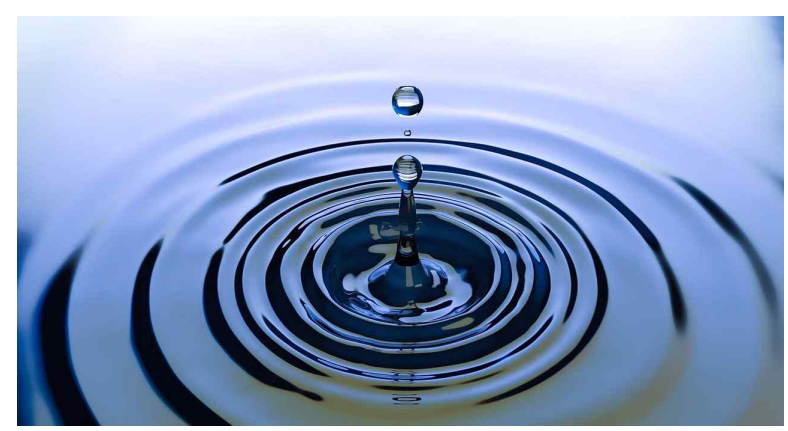

Fig. 1 Waterdrop

The force of the falling water droplet always goes toward its source: the center

The Sanskrit word lilla or lylla means the "divine play." The word is a way of describing all reality, including the cosmos, as the outcome of creative play by the divine absolute. Its meaning implies that play is connected to the act of creation. In that sense, if the personality of man is indeed formed and matured through play, play would be a reenactment of god's creative act. Man creates its inherent divinity through play, which is an act of participating in the work of creation by god and the maturation of man's personality. Just like meditation, 
prayer, art, dance and love, play is a process of discarding ego-centered consciousness and meeting the divine creativity inside us.

The statement above would seem absurd to those who consider play as nothing but fake and an entertainment for children. However, even when not explained in connection with the theory of archetypes, studies and literatures dealing with play show that play is clearly an archetypal experience. As an example, play historian Scott Eberle (2014) categorized the properties of play into: having no purpose, spontaneity, attraction, time-independent, decreased self-consciousness, extemporaneousness and a desire to continue the play (Jang, 2018). These attributes coincide with our experience of archetypal energies. When the archetypal energies are constellated in our psyche, our sense of purpose, driven by the ego, becomes weak; our ego-consciousness, in relation to time and number, diminishes; we behave spontaneously rather than according to a certain plan; we experience a strong emotional attraction and display extemporaneous behaviors; and we develop a desire to continue that experience. Jung says that just as weavers have the instinct to build a home, we follow archetypal patterns (While it is unsure whether we can say that animal instincts have archetypal properties, the weaver's behavior is, at least, instinctive.) (Jung, 1954/1993). Just as weavers have a certain principle, or impulse, to build a house, we engage in play due to an archetypal pattern to play. Of course, negative archetypal experiences do create a desire to break free from the pattern. One of the most common experience of archetypal image in our daily life is to fall in love. As seen in many films, novels and real-life experiences, falling in love neutralizes our goals, desires and ego intentions; creates intense emotions and strong attraction, which leads us to behave spontaneously; and develop the desire to continue that emotional experience. In other words, archetypal experiences obtained through archetypal images are not created, intended, planned or propelled by the ego.

Boo and Kang (2016), who conducted a phenomenological study on the moment of healing or the stillpoint experience in sandplay therapy process, found that both client and therapist commonly experienced immersion and transcendence at the moment of healing. According to the study, immersion is an experience involving happiness, excitement, peace tranquility and divinity. It also gives the feeling that time has stopped, and players seem to forget themselves and do 
Journal of Symbols \& Sandplay Therapy, Vol.11 No.2.

not become conscious of the therapist. On the other hand, transcendence involves complete support, acceptance, regulation, catharsis, liveliness and a feeling of change. Although the study participants were adults, thefindings suggest how children, who are less verbally expressive than adults, would experience stillpoint. The experiences of the research participants are coincide with the attributes of play mentioned above. Once children become immersed in play, they experience happiness and catharsis. They also learn to accept their outer situation-even when circumstances in life remain unchanged-and undergo changes in terms of their attitude, symptoms and relationships.

\section{Archetypal Experiences and Play Imagination}

Through imagination, archetypal experiences rise to consciousness in the form of images that involve emotional experiences (Jang, 2018). Imagination is not always limited to visual imagination. According to Jung, the imaginary fantasy process is a "subtle body": half physical and half psychological (1984/2007). In other words, imagination is part of human instinct and is not made consciously or intentionally but is "imagined" (Jung, 1984/2007). Charles Pierre Baudelaire (Yoon, trans, 2007) claimed that knowing, or intelligence, is nothing while imagining is everything. Imagination is the very source of our world; imagination creates the world. Images have many aspects. In order to understand how our psyche works and why it assigns strong emotions to images, we ought to analyze and also materialize what really happens to our psyche when we come across artistic images or simply imagine.

Images of the imagination is the metaphysics of the moment. Images depict a vision for the cosmos and convey the secrets of mind, man and objects. They are emotional and meaningful sensory experiences. Images are made up of several layers. They are associative and dynamic and constantly interact with memories and desires. The archetypal images of the imagination are not just about an object, but a way in which the object is realized. For example, Jorge Luis Borges (2000) says "the taste of the apple ... lies in the contact of the fruit with the plate, not in the fruit itself; in a similar way ... poetry lies in the meeting of poem and reader, not in the lines of symbols printed on the pages of a book. What is essential is the aesthetic act." Therefore, the most physical emotions arise from our understanding of 
them. Then the artistic images are fully materialized and exist in an emotional way in the physical world. As mentioned earlier, images are neither visual or auditory photographs nor symbolic or verbal objects outside of our daily lives. Works in art, literature and architecture arise from the body of the creator through the mediation of art images and return to the body through the audience's experience. Artistic images allow the entire humanity to engage in play and to feel our body.

This process is consistent with the way archetypal images are constellated in our psyche and eventually activated. Archetypes rise in the form of images, imaginations or fantasies accompanied by emotions, and they are projected onto symbols, which include play. Archetypes in the collective unconscious function in such a way because they have a certain teleology: to inform the conscious of the things that occur in the unconscious. In that sense, genuine imagination is a way for the conscious to know the unconscious (Jung, 1984/2002). That is why Jung himself became "humble" like little children and engaged in play, and also encouraged his patients to engage in imaginative activities similar to play. He says imagination comes through not only the head but also the body and therefore we need play, which involves the body.

However, there is insufficient explanation of the essentiality of imagination in play therapy. Assuming that play is the realization of imagination, it is necessary to explain the relationship between the origin of play imagination and its realization because, whether it be through play or a larger field of reality, imagination has a drive to be realized. In other words, the archetype - the origin of imagination-has a drive for realization. Like Jung, Palasmaa (2012) emphasizes imagination in the process of discovering images. He believes that symbols are discovered through the imagination, especially poetic imagination. As stressed many times by Jung, modern culture treats imagination as unscientific, non-objective and primitive and therefore claim it is not worth putting a lot of time and effort into understanding it. However, emotions are expressed through images, and the collective psyche of man (the archetypal psyche) expresses what man has developed, experienced and known intuitively through images. And as already mentioned above, images evoke intense emotions.

As Markell (2003) says, experiencing the mystic center sometimes provides client with the opportunity to access the energy of the whole psyche. This is the development of consciousness, or the death of an old consciousness - which is caught up in an inertia and therefore has lost 
Journal of Symbols \& Sandplay Therapy, Vol.11 No.2.

its energy, creativity and meaning of life-and the manifestation of a new consciousness. In other words, it rises as a form of imaginative and symbolic images that seek to inform us of the need to form a relationship with the Self. During the stillpoint experience, we can detect changes in our body movement and energy through careful observation, even unconsciously. Also, we can become aware of the invisible life orders or patterns found in the dynamics of daily life surrounding the stillpoint. Children can undergo these experiences unconsciously and thus experience changes in their attitude and emotions.

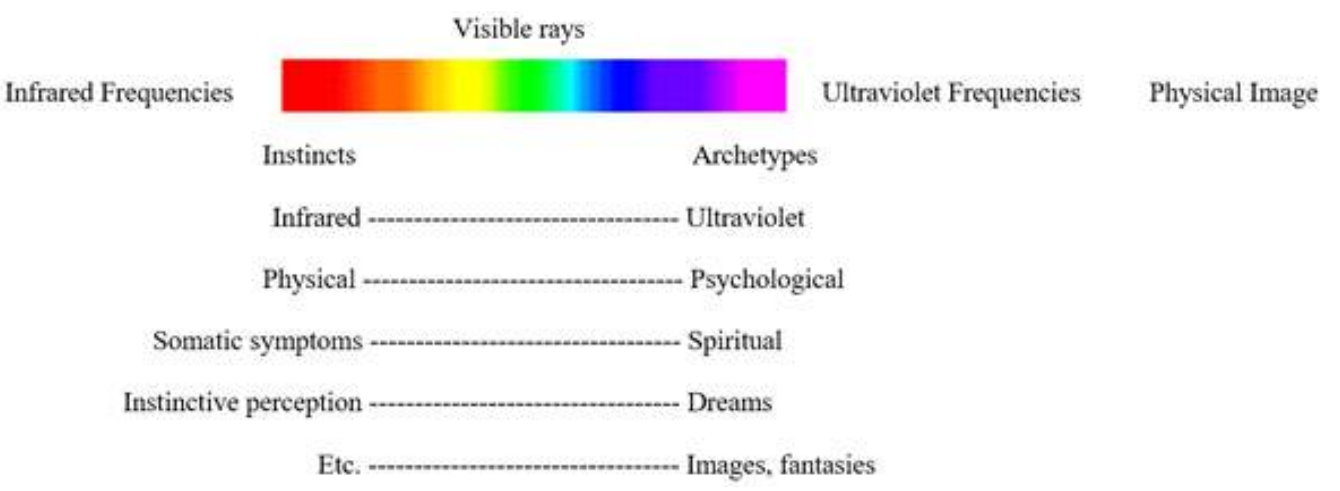

Fig. 2 A Summary of Jung's Concept on the Relationship between Archetypes and Instinct Source: Harris, J. (2001). Jung and Yoga: The Psyche-Body Connection. Toronto: Inner City Books.

This concept has been mentioned numerously not only in play but also art. Adolphe wrote, "To write meaningful music $\cdots$ the composer must find that sill point, and join the dance (1999, p. 17)." He specifically stated that the ego-consciousness should become quiet temporarily, i.e., that the ego should become smaller and become one with music. Smaller or weaker ego or consciousness would mean that we have to put down the ego intentions and assume an open attitude towards the unconscious so that imaginations can rise freely. Only then we will be able to create music that many can relate to. In this case, the possibility of experiencing that stillpoint phenomenon mentioned earlier becomes higher. Reaching the stillpoint requires descending to a place of pure experience that transcends thinking and intellectual cognition. That "place" is where children are entirely immersed in their play to completely exclude what is happening around them. This is why Nachmanovitch (1990), who wrote on musical 
improvisation and creative play, referred to the word lilla (or lylla) or "divine play" (p. 43). From the viewpoint of the therapist, a weakened ego-consciousness perhaps means the moment in play therapy when the therapist's negative counter-transference is discarded and, through the concentration of the archetypal energy, the boundary with the client disappears and the therapist becomes united with the client, thereby truly understanding the client. But it does not necessarily mean that the ego would disappear completely or sink. He believes that play makes man from a thinking being to a playing being, and that play is an act of the great divinity creating a paradise (Nachmanovitch, 1990).

As mentioned above, the Sanskrit word lilla or lylla means the "divine play," which implies that god being created the world through play. In other words, god did not create the world in a light, playful manner. Play is linked to creation and therefore divine. The god symbol, one of Jung's symbols of archetypal images, symbolizes the Self archetype. According to Jung's analytical psychology, all human beings have Self archetype upon birth and that archetype has the drive to be realized in each individual's life (Rhi, 2011). The drive for realization is the impulse to make the individual's life whole and the personality to develop as a whole. This drive is realized through play. In other words, play is a divine act of creation and is a process of realizing man as created by god (or whatever else it is called). This is why play is not a simple imitation or a representation of fantasy. And this is also precisely the reason why Jung extended the concept of the human nature to not only physical things like appetite, sexual desire and thirst but also creativity and activity (Jung, 1970). Because creativity and activity have the drive to be realized, just as instinct is realized almost compulsively, Jung defined them as human nature. Creativity and activity best define the characteristics of play. Play is the essentiality of human activity and creativity, which have a compulsion for realization.

\section{ARCHETYPAL TRANSFERENCE/COUNTERTRANSFERENCE AND SYNCHRONOCITY}

Jung(1967/1983). who first mentions the concept of transference and counter-transference, says counter-transference is much more comprehensive than transference, which is a theory of 
Journal of Symbols \& Sandplay Therapy, Vol.11 No.2.

classical psychoanalysis. Clients who are not able to live according to the dynamics of archetypes, especially the Self archetype, that aim to realize the whole of the personality perceive such dynamics as things of the external world and therefore project them to others. As a result, they want to be those others or desire for certain attributes that they have, which is transference. $\mathrm{He}$ stated that the client-therapist relationship is "a human encounter where love plays the decisive part" (1956/1990, p. 217). Jung symbolized this relationship through the image of alchemy to describe transference and counter-transference. An example is, in case of adults, the sexual drive. Here, the sexual drive does not refer to its literal meaning. Rather, it is the desire to integrate with one's inner world projected to the symbol of sexual union. The image of the transference/counter-transference relationship can also be expressed through a very primitive form of union. An example would be clients who want to go home with the therapist to become the therapist's children; to get inside the therapist's body to become the therapist's unborn child, regardless of the therapist's gender; or, in some cases, to eat the therapist's body to become one. This dynamics is often experienced in the client-therapist relationship in play therapy. As such, the drive for transference is first projected onto the outer world-first parents and, in a therapeutic relationship, the therapist-but it is ultimately a projection of an instinctive, unconscious structure of the psyche that allows personality to achieve whole, or allows us to unite with our selves. In other words, transference relationship is not a simple repetition of the clients' childhood experiences. Rather, it activates and projects archetypal, instinct drives that triggers the reenactment of childhood emotions. It is a phenomenon at the archetypal level in which clients seek to achieve unconscious union with the object of projection and ultimately union with their nature to become who they truly are.

Since our psyche consists of opposites - consciousness and unconsciousness - the inner world and the outer world be opposites as well, or form a mirror image. Therefore, having an intimate relationship with one's own nature-i.e., living with one's own emotional strength rather depending on others - can only be realized after experiencing an intimate relationship with others. Conversely, in order to form an intimate relationship with others, one must be able to do the same with his or her own nature. This transitional relationship occurs in psychotherapy, and, through transference, clients gain an understanding of themselves and shifts from 
dependence on the therapist to dependence on themselves.

Among alchemical symbolic images that Jung used to explain the transference/countertransference relationship is the image showing the King and Queen. The encounter between the King and Queen is the symbol of meeting, uniting and transforming. It symbolizes the double image, which is a essential attribute of a therapeutic relationship. It is also the process of the union between part of the client's consciousness and unconsciousness, i.e., the image of the client's psychic experience. The constellation of archetypal images entails emotional experiences, which strengthen life energy and thus bring healing. The image is symbolized by the union with the therapist, which is a heightened emotional experience that induces transformation in the client (Stevens, 1986). The reason behind this phenomenon is because archetypal energy has the teleology to function in this direction.

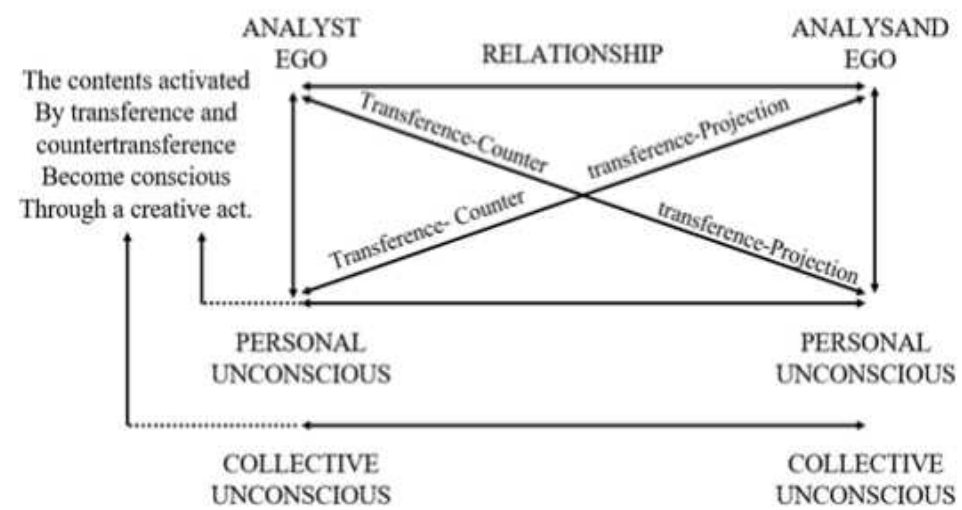

Fig. 3 Transference/Countertransference between Client and Therapist

Source: Verena Kast (1992, p. 144)

Fig. 3 is a diagram showing the directions in which the emotional transference/countertransference experience occurs between therapist and client. The emotional exchange between the two occurs at not only the conscious level but also the unconscious level. Moreover, it occurs at not only the personal unconscious level but also the collective unconscious level. This is called the archetypal transference. When the phenomenon occurs at the unconscious level for both parties, they perceive the other's emotions as their own. Sometimes they become aware of these emotions only after a certain period of time. From a neurobiology point of view, Schore 
Journal of Symbols \& Sandplay Therapy, Vol.11 No.2.

explained that the phenomenon is caused by the right-brain communication (2014; 2012). According to the concept of counter-transference, the therapist perceives what the client is experiencing the conscious or the unconscious as his or her own. And the client, too, can experience the therapist's emotions. It is especially true for children whose ego differentiation has not yet reached the level of adults'. Although the pattern of individualization may differ according to one's stage of development-e.g., infancy, childhood, adolescence and adulthoodthe basic underlying process can be regarded as identical. It is a progression from states of primitive identity and magic thinking to separation from that state and a resulting release of creative imagination leading to maturation of the ego expressed by saying that an extension of consciousness takes place (Fordham, 1985/2002). Therefore, the therapist becomes aware of the client's healing experience in therapy through an understanding of his or her own self. Through projection onto a motherly figure, i.e., the therapist, the child unites with the Great Mother. On the other hand, the therapist perceives the client as being in need of maternal care and feels that he/she needs to provide that care. Or sometimes, the therapist feels that he or she needs to be taken care of. While this may not be aware in the beginning, it ultimately brings healing. This process is projected and reflected in children's play. Therefore, a process of understanding the play is necessary.

Explanations based on multiple viewpoints can be made on the therapist's understanding of the projected fantasies through counter-transference. What these viewpoints have in common is that the projected materials can be understood through therapist's own experience. The theory of archetypes states that archetypes are a universal tendency of man. Therefore, the dynamics of the client can be understood through the therapist's own experience and a recognition of that experience. The human psyche has both instinctive, physical aspect and an archetypal aspect. These two aspects are not disconnected but are one; they have an opposite structure. In that regard, the experience of client and therapist can be explained by the phenomenon of synchronicity (Jung, 1984/2002). Synchronicity is a principle of non-causal connection and suggests that the world is connected as one. This principle connects elements that seem independent: inside and outside the therapy room, inside and outside of the client's psyche, and psychic events and physical phenomena. In other words, therapists can come to understand clients through their own experiences (Jung, 1984/2002). Simply put, what happens in the 
psyche also happens in the body, or the material world. Synchronicity does not have a dichotomic view of man's body and psyche but sees them as one.

If, from the viewpoint of quantum mechanics, we could explain that the influence therapist and client have on each other in the therapy space is caused by waves, then the therapist and the client can certainly feel and share each other's emotions (Lindorff, 2009). This occurs at not only the conscious level but also the unconscious and physical level. If only what is in the consciousness is shared, complex theories and explanations will not be necessary.

Neurobiology or brain science explains this phenomenon with the right brain. The right brain develops before the left brain-which is in charge of language, logic, judgment and ego intentions - at a time period critical for the formation of initial attachment. The right brain uses physical, nonverbal and silent communication methods through senses-e.g., skin sensation, sound, intonation, smell, body posture and eye contact-and ultimately forms images. Such sensory-based communication tends to occur unconsciously, unlike the left-brain communication. (Schore, 2014; Schore, 2012). This is consistent with the explanation that the body uses unconscious communication method. Zanocco and his colleagues (2006) pointed out the importance of empathic and bodily sensations that form the basis of the human psyche structure. While these researchers mentioned this function in reference to clients who have psychosis and are unable to express their experiences and emotions in a conscious, logical and ego-focused manner, it nevertheless emphasizes the importance of empathic, physical interaction when dealing with the children as well as the therapist's role to be aware of the unconscious and physical communication given that children's verbal capability and ego-differentiation level is behind than those of adults. The formation of images that do not follow any rules, not even the logical system, mentioned by Zanocco and his colleagues partially explain the process of manifestation of archetypal images.

Welling (2005), who describes transference/counter-transference in connection to therapist's therapeutic intuition, elaborates on the amount of information in the therapist's therapeutic intuition through different treatment phases. According to this theory, therapeutic intuition begins with the initial "detection stage" related to "arousal and attention function" and reaches the "metaphorical solution stage," where it hits the climax. In the metaphorical solution stage, which represents the right brain function, the therapeutic intuition appears in the form of motor 
Journal of Symbols \& Sandplay Therapy, Vol.11 No.2.

sensation, emotions, images, metaphors and words. This is the same for the client. The key is that therapeutic intuition has emotional attributes, and those attributes bring solutions to problems or alleviate them (Thiebaut de Scchotten at al., 2011; MacNeilage, Rogers, \& Vallorigara, 2009; Mashal, et al., 2007; Kuchinke et al., 2006; Naito et al., 2005; Asari et al., 2008; Raz, 2004; Casanto, 2003). This is precisely consistent with the experience of archetypal images, which accompany emotional experience. These intuitive forms are obscured and non-verbal, and can therefore be the basis for therapeutic use of play.

\section{CONCLUSION}

This study attempted to explain play, in terms of its origin and essentiality, based on analytical psychology. Until now, studies related to play have mainly dealt with the therapist's response, therapeutic attachment, the therapist's counter-transference experience and intervention in the parent-child relationship. There have been no studies on the origin or essentiality of play. Explanations of the origin and essential attributes of play provide clarification for the healing teleology of play, i.e., the reason why play is healing, and can provide grounds on why play has a strong relationship with healing in psychotherapy, which aims to heal through play. Archetypes, which are divine, have double attributes and teleology for healing through the constellation of emotional energies. Therefore play, which has an archetypal origin, has divine attributes and an ultimate teleology to integrate the personality and to bring healing. Archetypes are universal. Therefore, our archetypal experiences, which come through the constellation of archetypal energies, trigger archetypal experiences in others with whom we are in an intimate relationship. This also applies to therapeutic relationships. Given the archetypal attributes of the transference/counter-transference relationship, a common or shared experience arises and healing ultimately occurs. There is still, however, a need to conduct qualitative studies on the essentiality of the therapist's and client's experiences through the voice of the therapists as to how the divine play experience with its healing teleology is materialized for therapist and children in a play therapy setting. 
Jang, Mikyung $\cdot$ Lee, Yeo Reum / Numinose of Play and Its Healing Teleology

\section{References}

Adolphe, B. (1999). Of Mozart, parrots and cherry blossoms in the wind. New York: Limelight Editions.

Asari, T., Konishi, S., Jumura, K., Chikazoe, J., Nakamura, N., \& Miyashita, Y. (2008). Right temporopolar activation associated with unique perception. NeuroImage, 41(1), 145-152.

Baudelaire, C. P. Artist and Poet. (Trans. by Yoon. Y. E., 2007). Paju: Youlhwadang.

Borges, J. L. (2000). Epilogue for 'The Maker.' In J. L. Borges, Selected poems (Alexander Coleman ed.). New York/London: Penguin.

Boo, J. M., \& Kang, K. S. (2016). The phenomenological research on experiencing the stillpoint in sandplay therapy. Journal of Symbols \& Sandplay Therapy, 7(1), 1-38.

Brown, S., \& Vaughan, C. (2009). Play: How it shapes the brain, opens the imagination, and invigorates the soul. New York: Avery.

Casanto, D. (2003). Hemispheric specialization in prefrontal cortes: Effects of verbalizability, imageability and meaning. Journal of Neurolinguistics, 16, 361-382.

Eberle, G. S. (2014). The elements of play: Toward a philosophy and a definition of play. American Journal of Play, Q(2), 214-233.

Fordham, M. (1985/2002). Explorations into the self. London: Karnac.

Garvey, C. (1977). Play. Cambridge. MA: Havard University Press.

Harris, J. (2001), Jung and yoga: The psyche-body connection. Toronto: Inner City Books.

Hong, G. U., \& Lee, Y. S. (1998). Integrated understanding of human development. Seoul: Ehwa Womans University Publishing.

Huizinga, J. (1980). Homo Ludens; A study of the play-element in culture. Boston: Routlege \& Kegan Paul.

Jang, M. (2017). Analytical psychological sandplay therapy. Seoul: Hakjisa.

Jang, M. (2018). Play therapy. Seoul: Cangjisa.

Jasinski, T. J. (2014). Silence-a circumambulation. http://ejungian.com.

Jung, C. G. (1954/1993). The aims of psychotherapy. In C. G. Jung, Practice of psychotherapy: Essays on the psychology of the transference and other subjects (2nd ed.). CW 16. London: Routlege.

Jung, C. G. (1956/1990). Symbols of transformation (2nd ed.). CW5. Bollingen Series XX. Princeton, NJ: Princeton University Press.

Jung, C. G. (1960/1981a). On the nature of psyche. In C. G. Jung, The struture and dynamics of the psyche (2nd ed.). CW 8. Bollingen Series $X X$. Princeton, NJ: Princeton University Press.

Jung, C. G. (1960/1981b). Psychological factors in human behaviour. In C. G. Jung, The structure and 
Journal of Symbols \& Sandplay Therapy, Vol.11 No.2.

dynamics of the psyche (2nd ed.). CW 8, Bollingen Series $X X$. Princeton, NJ: Princeton University Press.

Jung, C. G. (1967/1983). General aspect of dream analysis. In C. G. Jung, Freud and psychoanalysis (2nd ed.). $C W$, Bollingen Series $I X$. Princeton, NJ: Princeton University Press.

Jung, C. G. (1970). Mind and earth. In C. G. Jung, Civilization in transition (2nd ed.). CW. 10. Princeton, NJ: Princeton University Press

Jung, C. G. (1984/2002). Archetyp und Unbewußtes. C. G. Jung Bd. 2. Walter-Verlag AG. (Trans, in to Korean in 2002 by Jung Institute of Korea).

Jung, C. G. (1984/2007). Erlösungsvorstellungen in der Alchemie. Grundwerk C. G. Jung Bd. 6. Walter-Verlag AG. (Trans, in to Korean in 2007 by Jung Institute of Korea)

Kast, V. (1992). The dynamics of symbols: Fundamentals of Jungian psychotherapy. New York: Fromm International.

Kuchinke, L., Jacobs, A. M., Võ, M. L. H., Conrad, M., Grubich, C., \& Herrmann, M. (2006). Modulation of prefrontal cortex activation by emotional words in recognition memory. Neuro Report, 17, 1037-1041.

Lindorff, D. (2009). Pauli and Jung: The meeting of two great minds. Wheaton, IL: Quest Books.

MacNeilage, P. F., Rogers, L., \& Vallorigara, G. (2009). Origins of the left and right brain. Scientific American, 301, 160-167.

Markell, M. J. (2003). Sand, water, silence: The embodiment of spirit. London: Jessica Kingsley Publishers.

Mashal, N., Faust, Hendler, M., \& Jung-Beeman, M. (2007). An fMRI investigation of the neural correlates underlying the processing of novel metaphoric expressions. Brain and Language, 100, $115-126$.

Nachmanovitch, S. (1990). Free play: The power of improvisation in life and the arts. Los Angeles, CA: Jeremy P. Tarcher, Inc.

Naito, E., Roland, P. E., Grefkes, C., Choi, H. J., Eickhoff, S., Geyer, S., et al. (2005). Dominance of the right hemisphere and role of Area 2 in human kinesthesia. Journal of Neurophysiology, 93, 1020-1034.

Otto, R. (1959). The idea of the holy. London: Oxford University Press.

Pallasmaa, H. (2012). The eyes of skin: Architecture and the senses. Chichester. West Sussex: John Wiley \& Sons Ltd.

Panksepp, J. (2007). Can play diminish ADHD and facilitate the construction of the social brain. Journal of Canadian Academy of Child and Adolescent Psychiatry, 16(2), 57-66. 
Raz, A. (2004). Anatomy of attentional networks. Anatomical Records, 281B, 21-36.

Rhi, B-Y. (2011). Analytical Psychology-C.G. Jung's thoughts on mind-. Seoul: Ilchokak Publishing.

Saemus, H. Personal Helicon, (Trans. by Lee. C. B.) http://egloos.zum.com/kangsiin/v/717972

Schore, A. (2014). Attachment, Neuroscience and Sandplay Therapy. Korean Society of Sandplsy Therapy 2014 International Conference.

Schore, A. (2012). The science of the art of psychotherapy. New York/Lodnon: Norton.

Spariosu, M. I. (1989). Dionysus Reborn: Play and the Aesthetic Dimension in Modern Philosophical and Scientific Discourse. New York: Cornell University Press.

Stein, Murray (1998). Transformation: emergence of the self. College Station, TX: Texas A\&M University Press.

Stevens, B. (1986). A Jungian perspective on transference and countertransference. Contemporary Psychoanalysis, 22(2), 185-201.

Sutton-Smith, B(2001). The Ambiguity of Play. Cambridge, MA: Havard University Press.

The National Institute of The Korean Language (2019). Standard Dictionary of Korean. http//stdict.korean.go.kr

Thiebaut de Schotten, M., Dell' Acqua, F., Forkel, S. J., Simmons, A., Vergani, F., Murphy, D. G. M., \& Catani, M. (2011). A lateralized brain network for visuospatial attention. Nature Neuroscience, 14, 1245-1246.

Von Franz, M-L. (1996). Interpretation of fairy tales. Boston, MA: Shambhala Publication Inc.

Weinber, B. (2015). Work of 2015 Winter sandplay training. Korean Society of Sandplay Therapy.

Welling, H. (2005). The intuitive process: The case of psychotherapy. Journal of Psychotherapy Integration, 15, 19-47.

Winnicott, D. (1971). Play and reality. New York: Basic Books.

Zanocco, G., De Marchi, A., \& Pozzi, F. (2006). Sensory empathy and enactment. International Journal of Psychoanalysis, 87, 145-158. 

상징과모래놀이치료, 제 11 권 제 2 호

Journal of Symbols \& Sandplay Therapy

2020, 12, Vol. 11, No. 2, 25-44.

doi https://doi.org/10.12964/jsst.20006

\section{놀이의 신성성과 치유 목적성}

\section{Numinose of Play and Its Healing Teleology}

장 미 경*

Jang, Mikyung
이 여 름 ${ }^{* *}$

Lee, Yeo Reum

\section{$<$ Abstract $>$}

In this article, we discuss the numinosity of play in terms of the origin or unique essentiality of play based on analytical psychology, rather than the evolutionary necessity of it in terms of only biological instinct or innate nature, or as something instilled through education. Attempts to explain play in this way lead to the conclusion that play is healing, and play has a powerful relationship with healing in psychotherapy. We also discuss the still point experience and transferencecountertransference and the relationship between the therapist and client regarding intersubjectivity, which are concepts related to the numinosity of play. In conclusion, the essentiality of play, which has an archetypal origin, is numinous and divine and has the ultimate teleology of integration and healing of personality, namely individuation. Other people in close relationships perceive the constellation of archetypal energies in an individual because of the working principle of archetype, and all humankind universally shares it and constellates archetypal energy to the other. This, of course, happens in therapeutic relationships, and finally it brings healing to both the client and therapist involved in archetypal play.

Keywords : numinosity, play, psychotherapy, still point, archetype, transference-countertransference

\footnotetext{
* 교신저자, 주저자, 남서울대학교 아동복지학과 및 동대학원 아동상담심리치료 전공 교수 (jangmiky45@gmail.com)

** 공동저자, 남서울대학교 아동복지학과 아동상담심리치료 전공 박사수료
} 
Journal of Symbols \& Sandplay Therapy, Vol.11 No.2.

\section{I. 서 론}

흔히 놀이는 어린 아동들에게만 해당하는 것이며 아동의 중요하지 않은 판타지나 상상에 불과하거나 일상경험의 단순한 반복이나 모방이라는 생각이 보편적이다. 심지어 일부 놀이 치료자들까지 이런 생각을 갖고 있기도 하다. 그러나 놀이를 논의한 문헌들을 보면, 놀이는 아동의 본능이자 타고난 것이라고 말하는 문헌들이 많다(홍강의-이영석, 1998; Penksepp, 2007; Garvey, 1977). 그럼에도 이들 문헌들은 놀이의 어떤 특성 때문에 그리고 어떤 근거로 이를 본능이라고 부르는 것인지에 대해 충분한 설명을 하고 있지 않다. 표준국어대사전에 의하면, 흔히 본능이란 어떤 생물조직체에게 생물학적으로 규정되고 사고나 정서의 개입 없이도 작동하는 타고난 동작이나 운동 또는 감정이나 충동을 의미하는 개념이다(국립국어 원, 2019). 놀이현상에는 놀이가 정서의 개입 없이도 일어나는 것이라는 본능적 정의로는 설명되지 않는 부분이 있다. 놀이의 개념에 관한 연구나 문헌에서 이에 대한 언급은 놀이 가 어떻게 생물학적 본능과 같고 다른지에 대한 설명이 없으며 더 나아가 대부분의 결과적 인 것으로서의 놀이의 효과를 설명할 뿐이다(Brown \& Vaughan, 2009). 즉 놀이의 발생기원 이나 본질적 특성에 대해서는 충분히 설명하고 있지 않다. 놀이의 발생기원이나 본질적 특 성은 놀이를 활용하는 심리치료에서 치료자와 내담자 사이에서 발생하는 놀이의 치유현상 을 설명해주기 때문에 중요하다.

놀이에 대한 개념이나 정의가 이렇게 불분명하고 미정리된 이유 중 하나는 놀이가 정의 하기 어려운 특성을 갖고 있는 것에 기인한다. 민속학자이자 놀이이론가인 Sutton-Smith (2001)도 놀이라는 단어가 놀이현상을 설명하기에는 모호하고 부정확다고 언급한 바 있다. 놀이를 정의하기 어렵다고 말하는 놀이이론가들의 놀이속성에 대한 설명은 놀이가 단순한 것이 아니며 놀이의 발생기원이나 본질에 관한 일부의 단서를 제공한다. 또한 이들은 놀이 를 초월적인 것이라고 정의한다. Spariosu(1989)는 놀이가 인간의 한두 가지의 영역이 아니라 모든 영역에 속한 것이라고 하였다. 특히 Eberle(2014)는 놀이를 자율적으로 조직되는 성장, 여정, 가속화, 개화(開花)과정, 움직임으로 보았다. 그것은 마치 건축가, 분자물리학자, 기상 학자, 동물행동학자, 정치철학자, 경제학자, 역사학자 등등이 자신의 기존 자원과 더불어 자 발적으로 “출현(emergence)”하는 모양과 구조로부터 나오는 어떤 과정을 경험하게 되며 이 과정의 결과에 더하여 새롭고, 일관적인 패턴, 구조, 속성을 가진 보다 복잡한 시스템을 만 드는 것과 같다고 했다. 이 자발적 구조는 상상이라고 할 수 있다. 그것은 과학의 시작은 상상이라는 표현과도 일치한다. 네덜란드의 놀이이론가인 Huizinga(1980)도 놀이는 우리의 의지에 따라 발생하는 것이 아니라는 언급을 통해 이와 같은 맥락을 표현했다.

예술을 창조적 상상에 의한 놀이로 본 Nachmanovitch(1990)는 이에 대한 비유로써 바이올 린 연주자를 예로 들면서 놀이를 매우 초월적이고 신성한 것으로 묘사했다. 그는 연주자가 
바이올린을 연주하기 위해 발을 대지에 굳건히 딛고 활을 켜기 위해 팔을 위로 드는 행동 을 영적 신성이 대지로 내려오고 영적 신성과 대지가 결합하여 대지 위에 '낙원'을 창조하 는 것으로 상징화했다. 연주자와 청중은 창조된 낙원의 결과로 큰 감동과 심리적, 영적 공 명을 경험한다. 그것은 또한 대뇌의 활동에 의한 연주일 뿐만 아니라 몸이 반응하고 몸과 뇌가 연결되어 하나가 되는 경험이기도 하다. 그런 의미에서 놀이는 신성성과 인간성, 뇌와 몸, 이성과 감성을 연결하는 역할을 한다. 아동뿐 아니라 성인도 감각적 놀이를 추구한다. 뛰고 뒹굴고 자신의 신체의 한계를 시험해 보기도 한다. 그것은 아마도 자신의 신체에 숨 어있는 신성성을 확인하는 또는 신성성이 발현하는 작업일 것이다. 시인인 Saemus Heaney도 보이지 않는 신성한 현실, 깊은 무의식에서 들려오는 영감에 대한 통찰을 보여주는 시를 창조했다. 그도 인간에게 임재 해 있는 놀이의 창조적 신성성을 직관했다.

어릴 적 어른들은 내가 바켓과 권양기가 있는 우물이나 낡은 펌프에 가는 것을 막지 못했다.

나는 시커먼 우물 속, 거기 갇힌 하늘, 그리고 수초와 곰팡이와 축축한 이끼 냄새를 좋아했다.

벽돌공장의 우물은 썩은 판자 뚜껑이 씨어져 있었다.

나는 바켓이 줄 끝에서 텀부덩 들어갈 때

그 요란한 부딪치는 소리를 즐겼다.

너무 깊어서 우물 속에 비치는 것은 보이지 않았다.

마른 돌 도랑 아래의 우물은

수조처럼 풀이 무성했다.

보드러운 수초 덮개 흙에서 긴 뿌리들을 끌어내면

하얀 얼굴이 바닥에 어릿거렸다.

- 이하 생략-

(Saemus Heaney, Personal Helicon, 출처: 이창배 역, http://egloos.zum.com/kangsiin/v/717972)

놀이는 또한 초월적 특성의 측면에서 원초적 침묵과 관련 있다. 기독교의 성서에 의하면, 신은 태초의 어둠과 고요라는 절대적 침묵 속에서 세상을 창조했다. 따라서 인간의 신성성 을 회복하는 상상의 창조적 과정은 침묵을 필요로 한다. 우리 모두는 어린 시절 놀이에 몰 두해 주변에서 돌아가는 것을 인식하지 못하거나 어딘가 다른 세계에 갔다 온 것 같은 몰 
Journal of Symbols \& Sandplay Therapy, Vol.11 No.2.

입의 느낌을 경험한 적이 있다. 그런 경험을 하고 나면 알 수 없는 충만감을 느낀다. Weber-Fechner의 법칙에 의하면, 자극량에 비례해 감각의 크기가 떨어진다. 즉 어두운 방에 전등 한 개를 켜는 것과 열 개에서 한 개를 더 켜는 것은 감각적으로 다르게 느껴진다. 첫 번째 어둠을 밝히는 전등에 비해 열 한 개째의 전등 빛에 대해서는 큰 차이를 느끼지 못한 다는 것이다. 이 말은 학습압력이나 휴대폰 같은 너무 많은 자극에 노출된 아동들이 몰입 을 통해 놀이의 신성성과 치유를 경험하기 힘들다는 것을 의미한다. 새벽 동틀 때의 고요 에서 신성성을 경험하는 것은 누구에게나 일반적인 것이다. 이것은 심리치료 장면에서 때 때로 놀이를 위한 침묵이 필요한 이유이기도 하다(장미경, 2017; Jasinski, 2014). 놀이치료를 통해 외부의 성인이 아동에게 무엇인가를 가르치는 것이 아니라 상상이미지라는 신성성을 통해 놀이 자체가 가르친다. 사회관념, 관습의 압력이나 양육방식 등에 의해 길들여진 자아 의 집착은 자유로워지기가 쉽지 않지만 상상을 만들어내고 그것을 삶에서 실현하게 만드는 신성성은 궁극적으로 치유를 가져오고 자아가 다시 성장하게 하거나 왜곡된 자아를 회복시 킨다. 다른 말로 하면, 놀이상상은 자아에 각인되어 있는 외상을 치유하는 목적성 기능을 한다. 그것이 놀이가 초월성과 신성성을 갖고 있는 이유이다.

Brown과 Vaughan(2009)은 놀이가 본능적임을 입증하는 근거로써 인간을 비롯한 포유동물 에게 놀이를 시작하는 본능적이고 내재화된 신호가 있다고 주장했다. 예를 들어, 아동이 미소를 보이며 시선을 응시하는 것, 동물이 눈을 무릎 뜨고 직선으로 상대를 향해 걸어가 지고 않고 둥글게 움직이거나 지그재그로 움직이는 행동은 상대에게 놀이의사를 보내는 신호라고 했다. 사냥을 하고 종족을 번식하는 행위에 비해 비효율적이고 비생산적으로 보 이는 놀이행위를 동물조차 하는 이유에 대해 그는 단순히 사냥이나 싸움을 연습하기 위한 것이 아니라 집단이나 무리 안에서 친밀한 관계를 맺고 관계에 필요한 신호와 동작을 연 습하는 것이라고 했다. 이것은 일견 모방학습이라고 단순히 말하기 쉬우나 분석심리학의 원형이론의 관점에서 보면 원형의 목적적 기능(teleological function) 즉 인간이 전체인격을 실현하며 살아가도록 안내하는 힘이라는 개념을 잘 반영하고 있는 예라고 할 수 있다. 구 체적인 놀이행동 보다는 놀이하게 만드는 힘 또는 본질인 원형적 충동(archetypal impulse)을 가리키는 말이다.

놀이를 설명하고 심리치료에 활용한 학자들 중 Winnicott(1971)은 놀이를 아동 정신의 분 리, 독립을 위한 중간현상 또는 중간개념으로 설명했다. 아동이 정신적으로 분화, 독립하기 이전에 현실과 정신, 타인과 자신, 현실과 상상을 구분하기 위한 중간적 국면이라는 것이 다. 이러한 개념 속에는 놀이는 본능적이기도 하면서 또한 정신적인 것이라는 의미가 내포 되어 있다. 이는 Jung(1960/1981)의 원형개념과 매우 유사하다. 놀이가 단순한 생물학적 본 능에 불과한 것이 아니며 그렇게 만드는 어떤 기제 또는 원리가 작동하고 있다는 전제를 갖고 있기 때문이다. 또한 그의 놀이 개념에 의하면, 놀이의 개념을 규정짓는 중간현상이라 
는 것이 말 그대로 중간에 끼인 과도기적 현상으로 끝나는 것이 아니라 이 중간은 인간이 죽을 때까지 계속 유지된다는 것을 인간은 경험을 통해 알고 있다는 것이다. 상상과 현실, 정신과 현실, 자신과 타인 사이에 들어 있는 이 중간은 성인의 상상과 현실 세계에 여전히 존재하며 이는 예술, 문화를 형성하는 요소로 계속 존재하기 때문이다. 이는 어린 시절의 놀이의 발생과 문화를 연결시키지는 않았지만 놀이를 문화현상의 기초로 본 Huizinga(1980) 의 놀이개념과 유사하다. 그렇다면 성인도 놀이가 필요하며 놀이는 인류문명의 원형적, 본 능적 충동이라는 결론을 피할 수 없다.

이 학자들의 설명은 당연하고도 자연스럽게 Jung의 원형(archetype) 개념을 떠올리게 한다 물론 Winnicott은 분석심리학의 원형이라는 개념을 사용하지 않았고 이 개념의 선천적 발생 에 대해서도 설명한 바 없다. 그러나 그는 이것이 인간의 보편적 특성이라는 것을 그의 체 험을 통해 알고 있었던 것 같다. Jung의 원형은 인류가 생긴 이래로부터 인간이 가지고 있 는, 타고난 것이며, 유전에 의해 전달되는 정신의 구조이다(Jung, 2014). 원형은 인간의 삶과 행동을 규정짓고 방향을 가져오는 준비성이자 그것을 실현시켜 나가는 본성이다. 특히 자 기원형(Self archetype)은 각 개인의 자아를 포함한 전체 정신의 중심이며 인간의 삶의 방향을 이끄는 기본 관념을 만들어내는 중심원형이다. 또한 자기원형은 정신의 조절 중심이다. 원 형은 시적 상상이고 판타지이며 상상과 환상 이미지를 통해 기본적인 행동충동의 형태로 의식에 출현한다(von Franz, 1996). 원형이미지가 배열될 때에는 강렬한 정서를 수반하며 특 히 자기원형 에너지의 배열은 초월적이고 신성하며 고양된 정서로 경험된다(Stein, 1998). 이 강렬한 정서는 치유를 가져오며 자아를 오랜 트라우마와 콤플렉스로부터 해방시킨다.

그러나 구체적 놀이행동이 유전되는 것이 아니다. 놀이하는 본능이 유전 되는 것처럼 원 형적 관념 자체가 유전되는 것이 아니며 원형적 관념을 형성할 수 있는 가능성이 유전되는 것이다(Jung, 1970). 그것은 한편으로 정신으로 발달하면서 또 한편으로는 본능에 그 뿌리를 두고 있는 동일한 것의 양극이다. 그렇기 때문에 Jung은 “상상력의 창조적 활동(놀이)은 아 무것도 아닌 것에 불과한 존재’라는 매임으로부터 인간을 자유롭게 해주며, 인간을 놀이 하 는 상태로 상승시켜준다고 했다(Jung, 1954/1993, p. 46). 하나의 인간으로서 아동뿐 아니라 성인조차 창조적 존재가 될 수 있는 것 그리고 전인격을 이용할 수 있게 되는 것은 오직 놀이할 때뿐이라는 것이다. Jung은 인간의 본능을 단순히 생물학적이고 사전적 의미 그대로 의 본능으로만 정의하지 않았다. 그는 본능을 배고픔, 갈증, 성욕, 활동성, 창조성의 다섯 개로 분류하였다(Jung, 1960/1981b). 놀이가 정신발달과 전혀 상관없는 본능적이기만 한 것 이 아니라 정신으로 발달하는 원형적인 것이며 원형적 에너지의 배열은 정서적으로 경험되 고 치유와 변화를 가져오는 것이라고 할 수 있다. 자연스럽고도 당연하게 상상 이미지는 어떤 형태로든 놀이화 된다. 놀이의 형태와 종류에 상관없이 인간이 놀이하고자 하는 충동 을 갖고 있는 것은 그런 이유에서 기인한다. 정서를 수반한 원형이미지의 배열은 부분적으 
Journal of Symbols \& Sandplay Therapy, Vol.11 No.2.

로만 발달해 있거나 갈등상태에 있는 의식에 대해 조절적 중심으로서 통합, 치유적으로 작 동하며 그것이 원형의 궁극적 목적성이다(Jung, 1960/1981a).

원형이미지와 함께 배열된 치유에너지는 인간정신의 보편성과 교류방식에 따라 함께 있 는 사람에게 영향을 미친다. 이런 에너지의 장은 서로에게 영향을 미치고 서로에게 치유적 기능을 갖는다. 놀이치료에서 단순이 놀아서, 웃어서 아동이 치유되는 것이 아니다. 아동과 치료자는 각자의 정신구조인 원형적 에너지 배열에 의해 영향을 받으며 갈등적 감정과 태 도 및 지각방식의 변화, 치유경험을 한다. 이 순간이 바로 변화의 순간이다. 놀이치료 장면 에서 많은 부모들이 부모가 긍정적으로 변하기 전부터 아동이 변했다고 보고하는 이유도 그것에 있다.

따라서 지금까지 놀이치료 분야에서 이루어지지 않은 치료자와 내담자의 치료과정에서 무엇이 그리고 언제가 놀이치료의 본질적인 변화의 순간인지 그리고 변화의 순간에 치료자 와 내담자의 관계 및 이 둘의 경험은 어떤 것인지 설명하는 시도가 필요하다. 놀이의 발생 기원에 관한 설명은 놀이가 발생하는 관계에 영향을 미치고 관계를 규정하게 되는 것이 당 연하다. 그러나 기존의 연구에서처럼 단순히 치료자가 내담아동을 공감해서, 이해해서 또는 치료자의 개입으로 부모의 태도나 양육방식이 바뀌어서 등의 이유만으로 치료가 이루어졌 다라고 말하는 것은 놀이의 본질에 대한 치료자의 무지를 의미하는 것이거나 놀이 자체가 갖는 치유적 기능 또는 목적성에 대한 무지를 의미하는 것일 수 있다. 그것은 치료자와 아 동의 관계본질이나 놀이가 아동과 치료자에게 갖는 본질적인 치유적 의미를 간과하는 태도 다. 놀이의 치유적 신성성을 놀이치료자가 설명하지 못하는 것이다. 단순히 매체 또는 수단 으로만 놀이를 활용한다면 그것이 굳이 놀이이어야 할 필요는 없을 것이다.

이러한 맥락에서 초보적이나마 본 논문에서는 분석심리학 및 놀이관련 문헌들을 고찰하 고 원형적 신성성의 측면에서 놀이의 치유목적성에 대해 논하고자 한다.

\section{ㅍ. 신성성(Numinose), 정점(Stillpoint) 경험}

\section{1. 신성성의 경험}

앞에서 기술한 바와 같이, Jung은 Winnicott이 암시적으로만 의미했던 놀이의 원리나 기제 를 원형(archetype)이라고 불렀다. 원형적 경험은 정서를 수반하는 경험이기 때문에 Jung에 의하면 원형은 체험되는 것이지 사고적으로 또는 지적으로 이해되는 개념이 아니다. von Franz(1996)는 오직 원형이미지가 인간에게 감정가치를 가지고 있을 때야만 그 이미지가 생 생하게 살아지고 깊은 의미를 갖게 된다고 했다. Jung이 기술한 것처럼 신성성, 창조성을 
상징하는 이 세상의 모든 대모(Great Mother)와 모든 성인들과 그 밖의 모든 것에 대한 지식 을 수집할 수 있겠지만 그것들에 대한 개인의 감정체험을 배제한다면 그 수집한 것들은 아 무런 의미가 없다(von Franz, 1996). 이 원형이미지에 대한 체험 즉 원형경험이 수반하는 정 서 체험 때문에 갈등의 해결과 통합 즉 치유 그리고 나아가 인격의 변화가 일어난다. 원형 은 인격의 일부분만이 아닌 전체를 실현 하려는 성향 내지 목적성을 갖고 있기 때문이다. 정서체험을 수반하지 않고서는 인격의 전체를 실현하기 위한 방향으로 움직여갈 힘을 가질 수 없다. 놀이치료에서 놀이경험은 정서를 수반하는 경험이며 단순한 모방이나 행동으로 이해되어서는 안 되는 이유가 여기에 있다. 모래놀이치료나 놀이치료 등 상징을 활용하는 심리치료가 치유적인 것은 바로 원형 이미지 체험이 수반하는 정서경험 때문이다. 이 정서 경험은 신성성(Numinous) 경험을 가져온다. 누미노스(Numinous)는 라틴어에 어원을 둔 개념 으로 본래 신적인 어떤 것, 신비한 것, 거룩한 것, 또는 초자연적인 것을 의미한다(Otto, 1959). 치료자와 내담자 관계에서의 경험으로 표현한다면 치료자와 내담자로 하여금 특별하 고 신비하며 심지어 신성한 느낌까지 갖게 하는 관계의 정서경험을 의미한다. 이 누미노스 경험은 인류의 문화와 경험의 여러 영역에서도 경험되고 기술되어 온 것이다. 즉 불교, 기 독교 신비주의와 같은 종교, 문학(시, 산문, 문학비평), 미술, 음악, 춤, 물리학, 그리고 요가, 침, 정(접)골요법, 부교감신경치료, 분석심리학과 같은 신체작업을 포함하는 치료기법 등의 다양한 장르에서 여러 가지 이름으로 불려온 경험이다(Weinberg, 2015).

\section{2. 정점(still point) 현상}

놀이의 원형적 경험 또는 신성성(Numinous)의 경험을 정점(still point) 경험으로 설명하기도 한다. 정점은 표현 그대로 조용한, 침묵의, 말 없음의 지점이다. 부정민과 강규숙(2016)에 의 하면, 정점체험은 과거, 현재, 미래의 시간들이 분열되지 않으면서도 서로 교차하고 합일하 면서, 단순한 시간의 흐름인 크로노스의 시간 뿐 아니라 의미의 시간인 카이로스의 시간이 흐르고, 주체와 타자가 공존하지만 동시에 구분이 없어지고 (더 나아가 삶과 죽음의 구분이 없어지며) 이 과정에서 신성함, 고요함, 평온함, 황홀감 등의 정서를 경험하는 것이다. 내담 자와 치료자 사이의 이러한 정점의 체험은 얼어붙어버린 정서, 미움, 증오, 분노, 억울함, 슬픔 등과 같은 것을 따뜻하게 녹여 용서, 화해와 사랑의 감정이 흐르게 한다. 그 결과 내 담자는 용기가 생기고 피해왔던 것들과 마주하게 되고, 분열되었던 또는 분화되지 않았던 내담자의 삶의 두 세계(내면과 외부, 마음과 현실 또는 대극적 갈등)가 다시 이어지는 초월 적 기능이 일어난다. 이런 경험은 내담자의 삶을 이제까지의 삶과 달라지게 한다(부정민, 강규숙, 2016, pp. 2-3).

더욱 강조하자면, still이라는 단어가 의미하는 바와 같이 정점 경험은 놀이가 단순한 행위 
Journal of Symbols \& Sandplay Therapy, Vol.11 No.2.

가 아니라 치유적 침묵 또는 고요와 관련된 놀이 그리고 내담자와 치료자를 구분하지 않고 배열되는 에너지의 장이라고 할 수 있다. 그러나 그것은 반드시 거창하기만 한 경험은 아 니다. 치료실에서 내담자와 함께 하는 순간에 치료자와 내담자는 말없이도 숙연하거나 소 름 돋거나 감동적인 경험을 한다. 또는 무엇인가가 통한다는 느낌, 아동을 깊이 이해하게 되는 경험, 아동이 무엇인가를 느끼고 있다는 감동 등을 경험한다. 때로 놀이치료자는 그 특별한 경험이 무엇인지 의식하지 못하다가 나중에서야 그 경험의 의미를 이해하거나 그것 이 내담아동과의 정점 경험이었음을 이해하게 되기도 한다. 한 아동사례를 들면, 부모의 오 랜 갈등과 이혼소송으로 인해 고통을 겪고 있던 여덟 살 남자아동은 와해될 듯 말 듯 아슬 아슬한 부모의 심리적 불안정성과 가족이 와해되기 직전의 불안을 떨어뜨리지 않고 놀잇감 을 높이 쌓는 놀이로 표현했다. 이 아동은 긴 시간 동안 아무 말 없이 오로지 쌓기에 집중 했다. 그러는 중 아동은 여러 차례 균형을 맞추지 못해 놀이감을 떨어뜨렸으나 쌓아올리기 를 반복했다. 아동은 왜 그렇게 놀이 하는지 설명하지 않았지만 치료자는 아동이 무엇을 하는지 무엇을 느끼는지 알 수 있었다. 한참의 침묵과 정적 그리고 그 속에서 아동의 소리 없는 에너지가 충만한 시간이 흐르면서 깊은 슬픔 그리고 아동의 스스로의 치유능력을 경 험한 치료자가 '지금은 아슬아슬 하더라도 쓰러지지 않고 잘 균형을 잡아서 네 마음이 편 했으면 좋겠다.라고 말하자 아동은 아무 말 없이 치료자의 눈을 들여다봤다. 의식적으로든 아니면 무의식적으로든 두 사람은 잘 알고 있었다. 아동은 가정과 부모의 불안과 갈등으로 부터 자신의 마음의 균형을 잡기 위해 애쓰고 있다는 것을. 그리고 크기, 모양, 무게가 서 로 다른 물건을 떨어뜨리지 않고 쌓기 위해서 무게 중심을 따라 쌓아야 한다는 것을 알고 있었던 것이다. 이 아동의 쌓아올리기 놀이가 원형적 경험이 아니라 그렇게 하게 하는 힘 이고 그래서 내적 갈등과 트라우마를 극복하는 방향으로 놀이하게 하는 힘으로 원형적이며 원형적 힘의 체험은 변화를 가져온다.

놀이의 이러한 특성과 관련하여 이 단어가 분명하게 언급한 된 곳 중 하나는 Markell의 저서인데 Markell은 자신의 저서 Sand, water, silence: The embodiment of spirit에서 내담자의 만다라 형태의 모래놀이사진과 함께 이 단어를 언급했다(Markell, 2003, p. 250). Markell은 여 기서 정점을 “신비한 중심"이라고 언급했는데 그것은 마치 에너지의 중심이며 그 주변의 모든 것이 이 신비한 에너지 중심을 중심으로 존재하게 되는 중심과 같은 것이다. 치유가 일어나는 순간은 두 사람의 정신의 본질적, 원형적 에너지 중심이 사진 속의 물방울이 중 심을 향하는 것처럼 중심으로부터 하나로 수렴하고 대면하게 되는 순간이다. 이러한 설명 은 자기(Self) 원형 이미지가 배열될 때 일어나는 경험과 일치한다. 


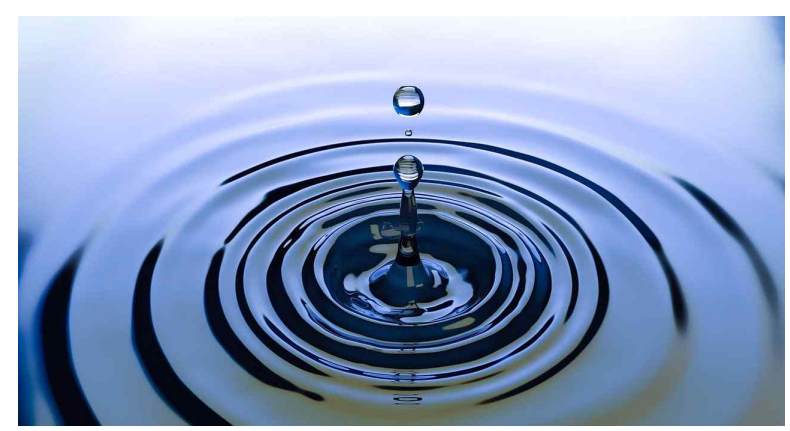

Fig. 1 물방울

떨어지는 물방울의 힘은 항상 그것의 근원인 중심을 향한다.

산스크리트어에서 놀이는 신성한 놀이를 의미하는 'lilla' 또는 'lylla'이다. 이는 성스러운 절 대자의 창조적 놀이를 통해 우주를 포함한 세계가 생겨났음을 뜻하는 말이다. 이 개념에는 놀이가 창조행위와 연결되어 있음이 함축되어 있다. 그런 의미에서 인간이 놀이를 통해 인 격을 형성, 성숙시켜 나간다면 인간의 놀이는 신의 창조행위를 재연한다는 의미가 된다. 인 간은 놀이를 통해 인간 안에 내재되어 있는 신성을 창조하며, 이는 신의 창조작업, 인격의 성숙화 작업이라는 창조에 동참하는 행위이다. 놀이는 명상, 기도, 예술, 춤, 사랑처럼 자아 중심적인 의식성을 버리고 내면의 신성한 창조성을 만나는 과정이다. 놀이라는 말을 별 것 아니고, 장난스럽고, 가짜고, 어린 아동들이나 하는 것쯤으로 생각하는 사람에게는 이상한 말이다. 그러나 원형이론과 연결시켜 설명한 것은 아니더라도 놀이의 개념들을 제시한 연구 나 문헌들에서조차 놀이는 분명히 원형적 경험임을 나타내고 있다. 그 예로서, 놀이 역사가 인 Scott Eberle(2014)는 놀이의 속성을 분명한 목적성 없음, 자발성, 끌림, 시간에 구애받지 않 음, 자아의식성의 감소, 즉흥성, 놀이를 지속하고자 하는 열망으로 구분하였다(장미경, 2018). 이는 원형에너지 경험과 정확히 일치하는 속성이다. 우리의 정신 안에 원형적 에너지가 배 열되면 자아의지에 의한 목적성이 약화되고 시간이나 숫자와 같은 자아의식성이 감소하며 계획보다는 즉흥성을 갖게 되고 정서적인 강력한 끌림과 자발성을 경험하며 그 경험을 지속 하고자 하는 열망을 갖게 된다. Jung(1953)은 위버새가 본능에 따라 집을 짓는 것처럼 우리 는 원형의 패턴을 따른다고 강조했다. 동물의 본성을 원형적 성질을 갖고 있다고 말할 수 있는지는 알 수 없지만 최소한 본능이다. 위버새가 집을 짓는 원리 즉 충동을 갖고 있는 것 처럼 우리는 원형적 놀이패턴에 의해 놀이를 하는 것이다. 물론 부정적인 원형경험은 그것 에서 벗어나고자 하는 열망을 갖게 한다. 일상에서 경험할 수 있는 가장 대표적인 원형이미 지 경험은 '사랑에 빠지는' 경험이다. 많은 영화, 소설, 실제 경험 등을 통해 알 수 있듯이 사랑에 빠지는 경험은 자아의 목표, 욕구, 자아의지를 무력화 시키고, 강렬한 정서를 갖게 하며, 이로 인한 강력한 끌림, 친밀한 관계의 속성 중 하나인 즉흥성, 그리고 그 감정적 경 
Journal of Symbols \& Sandplay Therapy, Vol.11 No.2.

험을 지속하고자 하는 열망과 자발성을 갖게 한다. 다시 말해 원형 이미지로 경험되는 원형 적 경험은 자아가 만들어내고 의도하며 계획하고 추진하는 경험이 아니다.

모래놀이치료 과정에서의 치유의 순간 또는 정점의 순간의 경험을 현상학적으로 연구한 부정민, 강규숙(2016)의 연구에서도 치유가 일어나는 순간에 내담자와 치료자의 공통 경험 은 몰입과 초월이었다. 몰입은 기쁨, 신남, 평화, 고요함, 시간이 정지한 느낌, 자신을 잊어 버린 느낌, 치료자를 의식하지 않음, 신성함의 경험이었으며, 초월은 완전한 지지, 수용, 조 절, 카타르시스, 생기, 변화된 느낌 등과 관련된 경험이었다. 이 연구는 성인을 대상으로 이 루어진 연구지만 연구결과는 언어적 표현이 성인에 비해 상대적으로 적은 아동의 정점 경 험을 짐작할 수 있게 해준다. 연구 참여자들의 경험이 위에서 언급한 놀이의 속성과 일치 하기 때문이다. 아동들이 놀이에 몰입하는 경험을 하고 나면 아동은 기쁨과 희열을 경험하 며 자신의 삶이 상황이 변하지 않았어도 상황을 수용하고 태도, 증상, 관계 등이 변화하는 모습을 보인다.

\section{3. 원형적 경험과 놀이 상상}

원형적 경험은 상상을 통해 처음에 이미지의 형태도 의식에 떠오르면서 감정적 경험을 수반한다(장미경, 2018). 상상은 반드시 시각적 상상만을 의미하지 않는다. Jung(1984/2007)에 의하면, 상상인 판타지 과정은 실체가 없는 허깨비가 아니라 절반은 신체적이고 또 다른 절반은 정신적인 미묘한 '몸체(subtle body)'이다. 즉 상상은 인간의 본성적 부분이며 의 식적, 의지적으로 만드는 것이 아니라 상상 '되어지는' 것을 의미한다(Jung, 1984/2007). Baudelaire(윤영애 역, 2007)는 아는 것 즉 지적인 것은 아무 것도 아니며 상상하기는 모든 것이라고 기술하였다. 상상은 우리 세계의 바로 근원이며 세계를 창조한다. 이미지는 여러 측면을 갖고 있다. 우리의 정신이 어떻게 작동하고 왜 이미지에 강한 정서를 부여하는지를 이해하기 위해 우리는 예술적 이미지에 접했을 때 또는 단순히 상상할 때 우리의 정신에서 정말로 무슨 일이 일어나는지 분석해야 하고 그것을 구체화해야 한다.

상상 이미지는 순간의 형이상학이다. 이미지는 우주에 대한 비전을 그리고 마음, 인간, 사물의 비밀을 전달한다. 이미지는 일깨워지는 것이며, 정서적이고 의미 있는 감각 경험이 다. 이미지는 여러 층으로 이루어져 있으며 연상적이고 역동적이며 기억 및 욕망과 지속적 으로 상호작용 한다. 원형적 상상 이미지는 단순히 사물에 관한 것이 아니라 사물의 실재 가 나타나는 방식이다. 예를 들어, Borges(2000)에 의하면, '사과의 맛은 사과라는 과일 자체 가 아니라 접시에 담겨 있는 사과의 맛이다. 시의 경우도 유사한데, 시의 의미는 책에 인쇄 된 문자에 있는 것이 아니라 시인과 독자가 만나는 데에 있다. 본질적인 것은 심미적 행위 이다. 때문에 가장 신체적인 정서는 각자가 그것을 이해함에서 생겨난다. 그런 후에 예술 
이미지는 완전히 구체화 되고 육적인 세상에서 정서적 방식으로 존재하게 된다. 앞서 언급 한 바와 같이, 이미지는 우리의 일상의 삶의 바깥에 있는 단순히 시각적, 청각적 사진이나 상징적, 언어적 존재가 아니다. 예술, 문학, 건축과 같은 영역의 작품은 예술 이미지의 중재 를 통해 만든 이의 몸에서 생겨나며 그것을 보는 사람의 경험을 통해 신체로 되돌아온다. 예술 이미지는 인간성 전체를 놀이하게 만들고 그 자신의 신체감각을 갖게 한다.

이것은 원형이미지가 우리의 정신 안에 배열되고 그것이 떠오르는 방식과 일치한다. 원 형은 이미지 즉 정서를 동반한 상상, 판타지의 형태로 떠오르고 그것이 투사된 것이 놀이 등의 상징이며 이 과정이 원형이 작동하는 방식이다. 집단무의식의 원형이 그러한 작용을 하는 것은 무의식 즉 원형이 갖고 있는 목적성 때문이다. 그 목적은 무의식에서 일어나는 것을 의식에 알리고자 한다. 그런 의미에서 참된 상상은 의식이 무의식을 알 수 있는 방법 이라고 할 수 있다(Jung, 1984/2002). 이러한 이유로 Jung은 스스로 어린 아이처럼 '낮아져' 놀이를 하거나 그의 환자들에게 놀이와 유사한 상상활동을 하게 했다. 상상은 머리만의 상 상이 아니라 몸의 상상이기도 하기 때문에 몸으로 하는 놀이가 필요하다는 것이다.

그러나 놀이치료에서 상상의 본질에 대한 설명은 부족하다. 놀이가 상상의 실현이라고 가정 한다면 놀이 상상의 근원과 이의 실현과의 관련성에 대한 설명이 필요하다. 상상을 놀이로 실현하든 더 큰 현실의 장에서 실현하듯 상상은 실현되고자 하는 충동성을 갖고 있다. 상상의 근원인 원형이 실현되고자 하는 충동을 갖고 있기 때문이다. Palasmaa(2012)도 Jung과 마찬가지로 이미지의 발견과정에서 상상을 강조하였다. 그는 상상, 특히 시적 상상 의 방식으로 상징이 발견된다고 하였다. Jung이 여러 차례 강조한 바와 같이 현대인의 문화 는 상상을 비과학적이고 객관적이지 않으며 원시적인 것으로 치부한다. 그렇기 때문에 많 은 시간과 노력을 기울일 만한 것이 못 되는 것이다. 그러나 정서는 이미지를 통해 표현되 며 인류의 집단정신(원형적 정신)은 인류가 발전시키고 경험해 온 그리고 선험적으로 알고 있는 것들을 이미지로 표현하는데, 이미 언급한 바와 같이 이 때 이미지는 강렬한 정서를 불러일으킨다.

Markell(2003)의 표현을 빌자면, 신비한 중심을 경험하는 것은 때때로 내담자에게 전체정 신의 에너지와 접촉할 수 있는 기회를 제공한다. 흔히 이것은 내담자의 의식의 발달, 심지 어 오래되고 타성에 빠져 에너지와 창조성 그리고 삶의 의미를 잃어버린 의식의 죽음과 새 로운 의식의 출현, 즉 자기(Self)와의 관계를 필요로 한다는 것을 알리고자 하는 상상적이고 상징적인 이미지의 형태로 떠오른다. 정점을 경험하는 동안 우리는 주의 깊은 관찰을 통해, 심지어 무의식적으로, 몸의 움직임과 에너지의 변화를 감지할 수 있다. 또한 정점을 둘러싼 일상의 역동에서 찾아 볼 수 있는 눈에 보이지 않는 삶의 순서와 패턴을 인식할 수 있다. 아동들은 이러한 경험을 무의식적으로 할 수 있으며 자신도 모르게 태도와 감정의 변화를 경험할 수 있다. 
Journal of Symbols \& Sandplay Therapy, Vol.11 No.2.

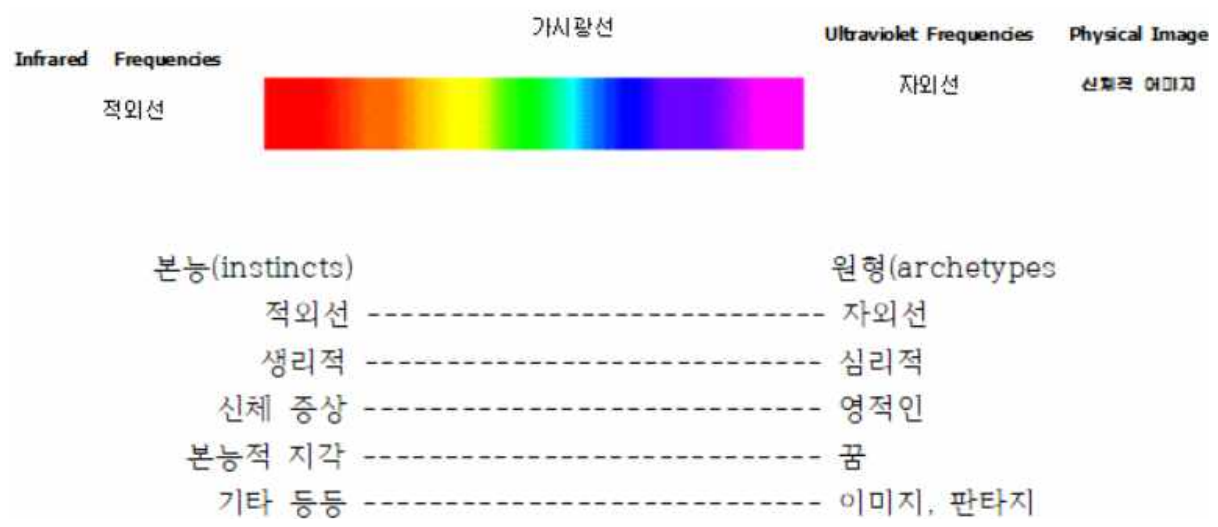

Fig. 2 원형과 본능의 관계에 대한 Jung의 개념 요약

출처: Harris (2001), Jung and Yoga: The Psyche-Body Connection. Toronto: Inner City Books.

이런 개념은 놀이 뿐 아니라 예술 분야에서도 수없이 언급되어 온 것이다. 작곡가인 Adolphe는 “의미 있는 음악을 창조하기 위해 $\cdots$ 작곡가는 정점을 발견하고 춤에 가담하여 야 한다(1999, p. 17)."라고 하였다. 이를 위해 자아의식성을 일시적긴 하지만 잠잠하게 하고 즉 자아가 작아지고 음악과 하나가 되어야 한다고 그는 구체적으로 언급하였다. 자아 또는 의식성이 작아지거나 약해진다는 것은 자아의지를 내려놓고 상상이 자유롭게 떠오를 수 있 도록 무의식에 대해 개방적 태도를 가져야 한다는 의미이다. 아마도 그럴 때에만이 많은 사람들이 공감할 수 있는 음악을 창조할 수 있다는 의미일 것이다. 그럴 때에 앞서 언급한 정점현상을 경험할 가능성이 높아지는데 정점에 이르는 것은 사고와 지적 앎을 초월한 순 수한 경험의 장소로 하강할 것을 요구하며 그 장소는 놀이하는 아동들이 완전히 그들 주변 에서 일어나는 일을 배제할 정도로 몰입하는 경험을 하는 '곳'이다. 이것은 즉흥연주와 창 조적 놀이에 관해 글을 쓴 Nachmanovitch(1990)가 새로와짐이 가능한 “릴라(lilla 또는 lylla)" 즉 “신성한 놀이"(p. 43)라고 기술한 이유이다. 치료자의 측면에서 본다면, 자아의식성이 약 해진다는 것은 아마도 놀이치료 장면에서 치료자의 부정적 역전이를 버리고 원형적 에너지 의 집중됨을 통해 내담자와의 경계가 없어지고 내담자와 하나가 됨으로써 내담자를 진정으 로 이해하게 되는 순간을 의미 한다. 그러나 자아가 완전히 없어지거나 함몰되는 것을 의 미하지는 않는다. 그는 놀이는 인간을 생각하는 인간에서 놀이하는 인간으로 만들어주며 놀이는 위대한 신성이 낙원을 만드는 행위라고 놀이를 묘사했다(Nachmanovitch, 1990).

위에서 언급한 바와 같이, "릴라(lilla 또는 lylla)"라는 단어는 "신성한 놀이"는 산스크리트 어에 어원을 둔 단어로써, 신이 세상을 창조할 때 놀이를 통해서 세상을 창조했다는 의미 를 담고 있다. 이 말은 신이 세상을 창조할 때 장난삼아 가볍게 세상을 창조했다는 뜻이 아니다. 이 표현은 놀이는 창조와 관련되어 있으며 신성한 것이라는 의미를 담고 있다. 
Jung의 원형이미지의 상징중 하나인 신(神)상징은 자기원형(Self archetype)을 상징한다. Jung의 분석심리학에 따르면, 모든 인간은 태어날 때부터 이 자기원형을 가지고 있으며 자기 원형 은 각 개인의 삶에서 실현되려는 충동을 갖고 있다(이부영, 2011). 실현의 충동은 개인의 삶 이 온전한 것, 인격이 전체로 발달하도록 하는 충동이다. 이 충동은 놀이를 통해서 실현된 다. 즉 놀이는 신성한 창조 행위이며 신(또는 그것을 무엇이라 부르든)이 인간을 창조한 그 대로를 삶에서 실현해 가는 과정이다. 즉 놀이는 신의 창조행위에 동참하게 만드는 신성한 작업이다. 그것이 놀이가 단순한 모방이나 단순한 판타지의 표출이 아닌 이유이다. 이것은 Jung이 인간의 본성을 식욕, 성욕, 갈증 같은 오직 신체적인 것에만 국한하지 않고 창조성, 활동성으로까지 확장한 이유다(Jung, 1970). 창조성과 활동성은 마치 본능이 강박적으로 실 현되려고 하는 것처럼 실현되려고 하는 충동을 가진 것이기 때문에 Jung은 이것을 인간의 본성으로 규정하였다. 창조성과 활동성은 바로 놀이의 특성을 가장 잘 정의해주는 표현이 다. 놀이는 강박적으로 실현되고자 하는 인간의 활동성과 창조성의 본성인 것이다.

\section{III. 원형적 전이/역전이 그리고 동시성}

정신분석학적 전통에서 전이, 역전이 개념을 처음으로 언급한 Jung은 역전이의 개념을 고전적인 정신분석 이론의 전이 개념보다 훨씬 더 포괄적 개념으로 언급하였다(Jung, 1967/1983). 단순히 과거에 강화 받지 못한 억압된 감정의 투사뿐만이 아닌, 여러 가지 이유 로 원형 특히 자기원형의 인격의 전체를 실현하려는 역동성에 따라 살지 못하는 내담자들 이 이러한 역동을 외적인 것으로 받아들이고 그것을 밖으로 투사하여 다른 사람에게 옮기 고 그 상대 또는 그 상대의 어떤 특성을 갈망하는 전이를 사례를 통해 기술하였다.

그는 치료자와 내담자의 관계에 대해 "사랑이 결정적 역할을 하는 인간적 대면(a human encounter where love plays the decisive part)(1946, p. 217)”이라고 언급한 바 있다. 이 대면을 이루는 치료자-내담자 관계를 Jung은 연금술의 이미지로 상징화하여 전이/역전이 관계를 기 술하였는데, 성인의 경우 성적 충동을 예를 들 수 있다. 여기서의 성적 충동은 문자 그대로 의 성적인 의미가 아니라 자신의 내면과 통합되고자 하는 욕구를 성적 결합이라는 상징에 투사한 것이라고 할 수 있다. 이외에도 이 전이/역전이 관계의 이미지는 매우 원초적 형태 의 합일 관계로도 이미지화 될 수 있다. 많은 내담자들이 치료자의 자녀가 되기 위해 치료 자와 함께 집에 가고 싶어 하거나 치료자의 성별과 관계없이 치료자의 태어나지 않은 자녀 가 되기 위해 치료자의 신체 내부로 들어가고 싶어 하거나 어떤 경우에는 하나가 되기 위 해 치료자의 몸을 먹고 싶어 하는 경우가 그 예이다. 이는 놀이치료의 치료자-아동 관계에 서 종종 경험되는 관계역동이다. 이렇게 전이충동은 처음에는 부모 그리고 치료관계에서는 
Journal of Symbols \& Sandplay Therapy, Vol.11 No.2.

치료자 즉 외부 세계에 투사되지만 궁극적으로는 자기 자신과의 합일 즉 인격이 전체를 이 루게 하는 정신내면의 본질적, 무의식적 구조의 투사이다. 다른 말로 하면, 전이관계는 단 순히 내담자의 어린 시절 경험의 반복이 아니라 어린 시절의 유아적 감정의 재연을 촉발시 키는 원형적, 본능적 충동이 심리치료에 의해 활성화되고 투사되는 것이다. 이것은 투사대 상이 되는 사람과 무의식적 합일을 이루려는 그리고 궁극적으로는 자신의 본성과 합일하여 온전한 자기 자신이 되려는 원형적 수준의 현상이다.

우리의 정신은 의식과 무의식의 구조라는 대극적 구조로 이루어져 있기 때문에 정신 내 면 세계와 외부 세계가 서로 대극 즉 거울 이미지를 이루고 있다. 따라서 자기 자신의 본 성과 친밀한 관계를 맺는 것, 즉 타인에 대한 의존적 마음이 아닌 자기 자신의 정서적 힘 으로 살아가는 것은 다른 사람과의 친밀한 관계를 경험한 후에야 실현 될 수 있다. 다른 말로 하면, 타인과 친밀한 관계를 맺을 수 있으려면 자신의 본성과 친밀한 관계를 맺을 수 있어야 한다는 것이다. 심리치료에서 이러한 과도기적 관계의 국면이 일어나며 전이관계를 통해 내담자는 자신을 경험하고 자신을 알게 되며 치료자에 대한 의존에서 스스로에 대한 의존으로 옮겨 간다.

Jung이 전이/역전이 관계를 설명하기 위해 사용한 연금술 상징 이미지 중에 왕과 왕비의 그림이 있는데 왕과 왕비가 만나는 장면은 과정 중에 만나고, 합일하고, 서로 변화하고 있 음의 상징이며 이는 치료적 관계의 본질적 속성인 이중적인 대극 이미지(double image)를 상 징한다. 그것은 또한 의식의 자신과 무의식의 자기의 일부가 만나고 합일하는 과정 즉 개 별 내담자가 겪고 있는 정신내적 경험의 이미지이기도 하다. 원형이미지의 배열이 정서경 험을 수반한다고 언급한 바와 같이, 이 경험은 삶의 에너지를 강화하여 치유를 가져온다. 이 이미지는 내담자를 변화하게 만드는 고도의 정서적 경험인 치료자와의 합일의 이미지로 상징화된다(Stevens, 1986). 결국 이런 현상이 일어나는 이유는 원형의 힘이 그 방향으로 작

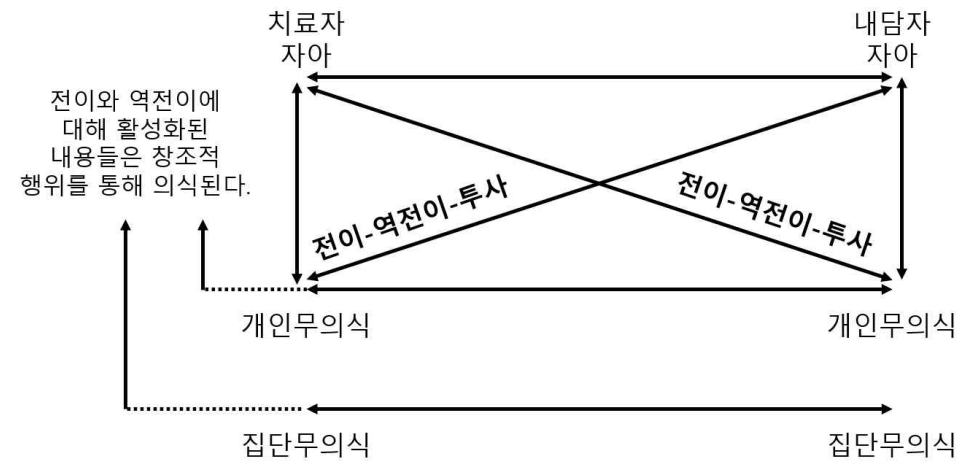

Fig. 3 치료자와 내담자의 전이/역전이

출처: Verena Kast (1992, p. 144) 
용하고자 하는 목적성을 갖고 있기 때문이다.

Fig. 3에 제시된 바와 같이, Jung이 치료자와 내담자 관계에서 발생하는 이 감정적 전이/ 역전이 경험의 방향을 기술한 다이어그램을 보면, 치료자와 내담자 관계의 감정적 교류는 의식 수준에서만 일어나지 않고 두 사람 사이에서 동시에 무의식적으로도 발생한다. 더 나 아가 개인 무의식 수준 뿐 아니라 집단 무의식 수준에서 발생하는데 이것을 원형적 전이라 고 한다. 두 사람 모두의 집단 무의식 수준에서 발생하면 상대방의 감정이 상대방의 것으 로 지각되지 않고 자신의 것으로 지각되거나 일정 시간이 지난 후에 의식되기도 한다. 신 경생물학의 관점에서 Schore는 이를 우뇌적 의사소통에 의해 발생하는 것으로 설명하였다 (Schore, 2014; Schore, 2012). 역전이 개념에 의하면, 내담자가 의식 또는 무의식에서 경험하 고 있는 것을 치료자가 역전이적으로 자신의 경험으로 인식하게 된다. 같은 원리에 따라 아동내담자 역시 치료자의 감정경험을 경험할 수 있다. 자아 분화가 성인에 미치지 못한 아동에게는 이러한 경향성이 더 강하게 발생할 가능성이 있다. 유아기, 아동기, 청소년기 및 성인기 등 발달 단계에 따라 나타나는 개성화의 양상은 다를 수 있지만 인격의 완성을 향한 충동인 기본적인 기저의 개성화 과정은 동일한 것이라고 볼 수 있다. 그것은 원시적 정체성과 마술적 사고로부터 분리이며 의식의 확장으로 표현되는 자아의 성숙을 가져오는 창조적 상상의 결과적 방출로의 발달이다(Fordham, 1985/2002). 따라서 아동이 치료과정에서 경험하는 치유적 순간을 치료자가 지각하는 것은 결국 치료자 자신에 대한 이해를 통해서 라고 할 수 있다. 아동은 치료자라는 모성적 대상에게 투사를 통해 대모(Great Mother) 에너 지와 일체성(Oneness) 도는 단일성(Unity) 상태에 놓이는 경험을 하게 되며 치료자는 모성적 돌봄을 필요로 하는 존재로서 내담자를 지각하여 돌봄을 주어야 한다고 느끼거나 치료자 자신이 돌봄을 필요로 한다고 느낀다. 이것은 처음에 의식 되지 않을 수 있지만 결과적으 로 이는 치유를 가져온다. 이러한 과정은 아동의 놀이에 투사되어 반영된다. 따라서 놀이내 용을 이해하는 과정이 필요하다.

치료자에게 투사된 이 판타지를 치료자가 역전이적으로 이해하는 것에 관해 여러 가지 관점의 설명이 이루어질 수 있다. 이 여러 가지 관점의 공통점은 이 투사된 내용이 치료자 자신의 경험을 통해 이해된다는 것이다. 원형이론에 따르면, 원형은 인간의 보편적 경향성 이므로 내담자의 이런 역동은 치료자 자신의 경험과 그 경험에 대한 인식을 통해 이해될 수 있는 것이다. 인간의 정신은 본능적이고 신체적 측면과 정신으로 발달하는 원형적 측면 을 갖고 있으며 이 둘은 단절된 것이 아니라 하나이며 대극적 구조를 갖고 있을 뿐이다. 이 설명은 동시성(synchronicity) 현상으로 치료자와 내담자의 경험을 설명할 수 있게 한다 (Jung,1984/2002). 동시성 개념은 비인과적 연결원리를 말하는 것으로써 세계가 하나로 연결 되어 있음을 의미한다. 이 동시성 원리 때문에 치료실 내부와 외부, 내담자 정신의 외부와 내부, 정신적 사건과 물리적 현상의 일치를 경험하며 독립된 것으로 보이는 개체들 간에 
Journal of Symbols \& Sandplay Therapy, Vol.11 No.2.

연결성을 나타낸다. 이는 치료자가 자신의 경험을 통해 내담자를 이해할 수 있음을 의미한 다(Jung, 1984/2002). 간단히 말하면 정신에서 일어나고 있는 일은 신체 즉 물질세계에서도 일어난다는 것이다. 이것은 인간의 육체와 정신을 이분법적으로 나누지 않고 하나의 존재 로서 보는 관점에 근거한다.

또한 양자역학의 관점에서 치료자와 내담자가 치료공간에서 서로에게 영향을 주고받는 것을 파동에 의한 것이라고 설명 할 수 있다면 치료자와 내담자는 당연히 서로의 정서를 느끼고 공유한다(Lindorff, 2009). 이는 의식적 수준 뿐 아니라 무의식적, 신체적 수준을 포함 한다. 의식적인 것만이 공유된다면 복잡한 이론과 설명이 필요하지 않을 것이다.

신경생물학 또는 뇌과학에서는 이를 우뇌적으로 설명하고 있다. 언어, 논리, 판단, 자아의 지적 측면을 관장하는 좌뇌에 비해 우뇌는 초기 애착형성의 결정적 시기에 좌뇌 보다 먼저 발달하며 감각 즉 피부감각, 소리, 억양, 냄새, 자세, 눈맞춤 등의 신체적, 비언어적, 암묵적 의사소통 방식을 사용하며 궁극적으로 이미지를 형성한다. 그러나 이러한 감각적 의사소통 은 좌뇌적 소통과 달리 무의식적으로 이루어지는 경향을 갖고 있다(Schore, 2014; Schore, 2012). 몸은 무의식적 의사소통 방식을 사용한다는 설명과 일치한다. 같은 맥락에서 Zanocco 와 그의 동료들(2006)은 공감적, 신체적 감각의 중요기능과 발달하는 인간정신구조의 기초 를 이루는 공감적 신체감각의 중요성을 지적했다. 물론 이 연구자들은 정신증을 가지고 있 어서 의식적, 논리적, 자아중심적으로 자신의 경험과 감정을 표현하기 어려운 내담자들을 대상으로 이 기능을 언급했지만 아동의 언어화와 자아분화가 성인에 비해 약하다는 측면에 서 아동과의 치료에 공감적, 신체적 상호작용의 중요성 그리고 무의식적, 신체적 의사소통 을 알아차리는 치료자의 중요성이 강조된다고 할 수 있다. "어떤 법칙도 따르지 않는, 심지 어 논리체계도 따르지 않는 이미지의 생성”(p.145)이라는 이들의 표현은 원형이미지의 발현 과정을 부분적으로 설명해 준다.

전이/역전이를 치료자의 치료적 직관과 연결 지어 기술한 Welling(2005)은 치료자의 치료 적 직관에 포함된 정보의 양을 치료단계 별로 나누어 설명하였다. 이 단계 이론에 의하면, 치료적 직관은 “각성 및 주의 기능”과 관련된 초기 “탐지 단계”로 시작하여 “은유적 해결 단계”에 이르러 절정에 이게 되는데 특히 우뇌적 기능을 대표하는 은유적 해결 단계에서는 치료적 직관이 운동감각, 감정, 이미지, 은유, 단어 등의 형태로 나타난다. 이것은 내담자에 게도 마찬가지이다. 여기서 중요한 것은 치료적 직관이 운동감각, 감정, 이미지, 은유, 정서 단어 등의 형태와 같은 정서적 특성을 갖고 있으며 정서적 특성은 문제의 해결이나 완화를 가져온다는 것이다(Thiebaut de Scchotten at al., 2011; MacNeilage, Rogers, \& Vallorigara, 2009; Asari et al., 2008; Mashal, et al., 2007; Kuchinke et al., 2006; Naito et al., 2005; Raz, 2004; Casanto, 2003). 이는 감정적 경험을 수반하는 원형이미지 경험과 정확히 일치한다. 이러한 직관적 형태들은 가려지고 비언어적인 것이어서 놀이를 치료적으로 사용할 수 있는 근거가 
될 수 있을 것이다.

\section{$\mathrm{IV}$. 결 론}

본 연구에서는 분석심리학을 기반으로 놀이의 발생기원이나 본질적 특성의 측면에서 놀 이를 설명하고자 하였다. 지금까지의 놀이관련 연구들은 주로 치료자의 반응, 치료적 애착, 치료자 역전이 경험, 아동-부모 관계에의 개입 등의 측면에서만 이루어져 왔으며 놀이의 발 생기원이나 본질적 특성에 대한 연구들은 이루어지지 않았다. 놀이의 발생기원과 본질적 특성의 측면에 대한 설명은 놀이의 치유 목적성 즉 놀이가 치유적인 이유를 설명해주며 놀 이를 통해 치료를 이루고자 하는 심리치료에서 놀이가 치유와 강한 관계를 맺고 있는 이유 를 설명할 수 있는 근거가 된다. 결론적으로 신성성을 특징으로 하는 원형이 이중적 특성 과 감정적 에너지 배열로 치유를 가져오는 목적성을 갖고 있기 때문에 원형적 근원을 갖고 있는 놀이의 본질적 특성은 신성한 것이며 인격의 통합과 치유라는 궁극적인 목적성을 갖 고 있다. 원형에너지의 배열을 통해 경험하게 되는 원형적 경험은 인류보편성이라는 원형 의 특성으로 인해 친밀한 관계에 있는 사람들에게도 지각되며 원형경험을 유발한다. 이것 은 치료관계에도 해당되며 전이-역전이 관계의 원형적 특성으로 인해 공통의 경험이 일어 나고 결과적으로 치유가 일어난다. 그러나 앞으로 이 신성하고 치유 목적성을 가진 놀이경 험이 놀이치료 장면에서 치료자와 아동에게 어떤 현상으로 구체화되는지와 관련하여 두 사 람의 경험의 본질을 치료자들의 목소리를 통해 질적으로 연구될 필요가 있다.

\section{참고문헌}

국립국어원 (2019). 표준국어대사전. http//stdict.korean.go.kr

부정민, 강규숙 (2016). 모래놀이치료에서 정점체험에 대한 현상학적 연구. 상징과 모래놀이치

료, 7(1), 1-30.

이부영 (2011). 분석심리. 서울: 일조각.

장미경 (2017). 분석심리학적 모래놀이치료. 서울: 학지사.

장미경 (2018). 놀이치료. 서울: 창지사.

홍강의, 이영석 (1998). 인간발달의 통합적 이해. 서울: 이화여자대학교 출판부.

Adolphe, B. (1999). Of Mozart, parrots and cherry blossoms in the wind. New York: Limelight Editions. 
Journal of Symbols \& Sandplay Therapy, Vol.11 No.2.

Asari, T., Konishi, S., Jumura, K., Chikazoe, J., Nakamura, N., \& Miyashita, Y. (2008). Right temporopolar activation associated with unique perception. Neurolmage, 41, 145-152.

Baudelaire, C. P. 윤영애 역 (2007). 화가와 시인: 보들레르 미학의 등대 들라크루아, 그에게 바치 는 미술론. 파주: 열화당.

Borges, J. L. (2000). Epilogue for 'The Maker.' In J. L. Borges, Selected poems (Alexander Coleman ed.). New York/London: Penguin.

Brown, S., \& Vaughan, C. (2009). Play: How it shapes the brain, opens the imagination, and invigorates the soul. New York: Avery.

Casanto, D. (2003). Hemispheric specialization in prefrontal cortes: Effects of verbalizability, imageability and meaning. Journal of Neurolinguistics, 16, 361-382.

Eberle, G. S. (2014). The elements of play: Toward a philosophy and a definition of play. American Journal of Play, G(2), 214-233.

Fordham, M. (1985/2002). Explorations into the self. London: Karnac.

Garvy, C. (1977). Play. Cambridge. MA: Havard University Press.

Harris, J. (2001). Jung and Yoga: The Psyche-Body Connection. Toronto: Inner City Books.

Huizinga, J. (1980). Homo Ludens; A study of the play-element in culture. Boston: Routlege \& Kegan Paul.

Jasinski, T. J. (2014). Silence-a circumambulation. http://ejungian.com.

Jung, C. G. (1954/1993). The aims of psychotherapy. In C. G. Jung, Practice of psychotherapy: Essays on the psychology of the transference and other subjects (2nd ed.). CW 16. London: Routlege.

Jung, C. G. (1956/1990). Symbols of transformation (2nd ed.). CW5. Bollingen Series XX. Princeton, NJ: Princeton University Press.

Jung, C. G. (1960/1981a). On the nature of psyche. In C. G. Jung, The struture and dynamics of the psyche (2nd ed.). CW 8. Bollingen Series $X X$. Princeton, NJ: Princeton University Press.

Jung, C. G. (1960/1981b). Psychological factors in human behaviour. In C. G. Jung, The structure and dynamics of the psyche (2nd ed.). CW 8, Bollingen Series $X X$. Princeton, NJ: Princeton University Press.

Jung, C. G. (1967/1983). General aspect of dream analysis. In C. G. Jung, Freud and psychoanalysis (2nd ed.). $C W$, Bollingen Series IX. Princeton, NJ: Princeton University Press.

Jung, C. G. (1970). Mind and earth. In C. G. Jung, Civilization in transition (2nd ed.). CW. 10. Princeton, NJ: Princeton University Press

Jung, C. G. (1984/2002). 원형과 무의식. 한국융연구원 C. G., 융 저작번역서 2권. 솔출판사.

Jung, C. G. (1984/2007). 연금술에서 본 구원의 관념. 한국융연구원 C. G,. 융 저작번역서 6권. 솔 
출판사.

Kast, V. (1992). The dynamics of symbols: Fundamentals of Jungian psychotherapy. New York: Fromm International.

Kuchinke, L., Jacobs, A. M., Vo, M. L. H., Conrad, M., Grubich, C., \& Herrmann, M. (2006). Modulation of prefrontal cortex activation by emotional words in recognition memory. Neuro Report, 17, 1037-1041.

Lindorff, D. (2009). Pauli and Jung: The meeting of two great minds. Wheaton, IL: Quest Books.

MacNeilage, P. F., Rogers, L., \& Vallorigara, G. (2009). Origins of the left and right brain. Scientific American, 301, 160-167.

Markell, M. J. (2003). Sand, water, silence: The embodiment of spirit. London: Jessica Kingsley Publishers.

Mashal, N., Faust, Hendler, M., \& Jung-Beeman, M. (2007). An fMRI investigation of the neural correlates underlying the processing of novel metaphoric expressions. Brain and Language, 100, 115-126.

Nachmanovitch, S. (1990). Free play: The power of improvisation in life and the arts. Los Angeles, CA: Jeremy P. Tarcher, Inc.

Naito, E., Roland, P. E., Grefkes, C., Choi, H. J., Eickhoff, S., Geyer, S., et al. (2005). Dominance of the right hemisphere and role of Area 2 in human kinesthesia. Journal of Neurophysiology, 93, 1020-1034.

Otto, R. (1959). The idea of the holy. London: Oxford University Press.

Pallasmaa, H. (2012). The eyes of skin: Architecture and the senses. Chichester. West Sussex: John Wiley \& Sons Ltd.

Panksepp, J. (2007). Can play diminish ADHD and facilitate the construction of the social brain. Journal of Canadian Academy of Child and Adolescent Psychiatry, 16(2), 57-66.

Raz, A. (2004). Anatomy of attentional networks. Anatomical Records, 281B, 21-36.

Saemus, H. Personal Helicon, 이창배 역, http://egloos.zum.com/kangsiin/v/717972

Schore, A. (2014). 애착, 신경과학과 모래놀이치료. 한국임상모래놀이치료학회 2014 국제학술대 회 자료집.

Schore, A. (2012). The science of the art of psychotherapy. New York/Lodnon: Norton.

Spariosu, M. I. (1989). Dionysus Reborn: Play and the Aesthetic Dimension in Modern Philosophical and Scientific Discourse. New York: Cornell University Press.

Stein, Murray (1998). Transformation: emergence of the self. College Station, TX: Texas A\&M University Press. 
Journal of Symbols \& Sandplay Therapy, Vol.11 No.2.

Stevens, B. (1986). A Jungian perspective on transference and countertransference. Contemporary Psychoanalysis, 22(2), 185-201.

Sutton-Smith, B. (2001). The Ambiguity of Play. Cambridge, MA: Havard University Press.

Thiebaut de Schotten, M., Dell'Acqua, F., Forkel, S. J., Simmons, A., Vergani, F., Murphy, D. G. M., \& Catani, M. (2011). A lateralized brain network for visuospatial attention. Nature Neuroscience, 14, 1245-1246.

Von Franz, M-L. (1996). Interpretation of fairy tales. Boston, MA: Shambhala Publication Inc.

Weinber, B. (2015). Work of 2015 Winter sandplay training. Korean Society of Sandplay Therapy.

Welling, H. (2005). The intuitive process: The case of psychotherapy. Journal of Psychotherapy Integration, 15, 19-47.

Winnicott, D. (1971). Play and reality. New York: Basic Books.

Zanocco, G., De Marchi, A., \& Pozzi, F. (2006). Sensory empathy and enactment. International Journal of Psychoanalysis, 87, 145-158. 